Article

\title{
Getting Environmental Information from Construction Cost Databases: Applications in Brazilian Courses and Environmental Assessment
}

\author{
Luis Claudio A. Borja ${ }^{1,2, * \mathbb{C}}$, Sandro Fábio César ${ }^{3}$, Rita Dione A. Cunha ${ }^{3}$ and Asher Kiperstok ${ }^{2}$ \\ 1 Federal Institute of Bahia (IFBA), BR 324-km 102.11, S/N-Aviário, 44135-000 Feira de Santana, Brazil \\ 2 Post-Graduate Program in Industrial Engineering (PEI), Federal University of Bahia (UFBA), \\ Aristides Novis, 02, Federação, 40210-630 Salvador, Brazil; asher@ufba.br \\ 3 Post-Graduate Program in Civil Engineering (PPEC), Federal University of Bahia (UFBA), Aristides Novis, \\ 02, Federação, 40210-630 Salvador, Brazil; sfcesarpaz@uol.com.br (S.F.C.); ritadi@uol.com.br (R.D.A.C.) \\ * Correspondence: luisborja@ifba.edu.br or borja.ifba@gmail.com; Tel.: +55-75-99193-2060 or +55-75-3022-6633
}

Received: 30 November 2018; Accepted: 20 December 2018; Published: 1 January 2019

\begin{abstract}
The traditional decision-making process in construction is still driven by factors such as cost and time, not adequately addressing indicators to control their environmental impacts. So, how to improve environmental communication to incorporate sustainable building practices. The incorporation of environmental indicators may enlarge the scope of construction management tools. In the case of cost databases, widely used in the construction sector, this action can contribute to the communication and dissemination of environmental practices. This paper mapped 24 indicators from construction cost databases to assess their ability to communicate and disseminate environmental information. The research comprised: (a) a review of the use of cost bases in the environmental study, (b) identification of the most cited bases in 27 Brazilian civil engineering courses, and (c) analysis of the selected databases through of the assessment matrix, it crosses cost data versus environmental information. CYPE, TCPO, and ORSE presented performance medium, and higher results than SINAPI, BDCCM, and BCCA. The tools presented low control over environmental information, such as water and energy consumption, machine circulation and pollution generation. However, it has been observed that when adding environmental indicators, these tools can contribute significantly to disseminate good practices in its wide user base.
\end{abstract}

Keywords: cost databases; sustainable development; construction industry; environmental aspects; construction management; construction site

\section{Introduction}

The definition and implementation of actions in the search for more sustainable urban systems and constructions are directed by social, economic and financial, institutional, technological, personnel involved, knowledge and innovation, all taking into account the local context and its complexities [1]. Economic and financial factors include costs during the life cycle. In this sense, the challenge is to combine the lowest environmental impact with the cost-optimal during the life cycle [2], reducing the construction process externalities [1].

Initially, life-cycle costs (LCC) emerged to support the project economic choice. In general, such analysis begins with the identification of the constructive activities involved, followed by identification and measurement of their inputs and outputs in terms of time and cost for acquiring materials and services. In recent decades, with the consolidation of the concept of sustainability (balance among the economic, environmental and social dimensions), the need to harmonize economic costs and socio-environmental impacts has increased. Thus, the LCC began to seek to 
reconcile the economic dimension with the environmental dimension in the choice of low-impact products and processes [3]. Similarly, economic costs have also been incorporated into certification and environmental assessment systems, such as Leadership in Energy and Environmental Design (LEED), British Building Research Establishment Environmental Assessment Method (BREEAM), and Comprehensive Assessment System for Building Environmental Efficiency (CASBEE) [4-6]. In the environmental literature, this integration involves the optimization of economic costs and environmental costs, for example, the reduction of resource consumption and waste generation [7], use energy efficiency [8] and reduction of pollutant emissions [9].

In this sense, an economic tool such as LCC can work in conjunction with environmental analysis methodologies during the construction life-cycle. Applications for LCC can be observed in Life-cycle assessment (LCA) [10,11], Life-cycle carbon emissions (LCCE) [12], Life-cycle energy analysis (LCEA) [13]. However, combined analysis of LCC, LCA, and LCCE presents challenges, which require time and research to address the different environmental, economic and social requirements. In addition, new approaches have emerged which correlate economic costs and environmental impacts to project management and construction practices, through the adoption of technologies such as BIM $[12,14,15]$ and methodologies such as Lean Construction [16].

The choice of the evaluation model traditionally also has an impact on the profile of the data to be adopted. Thus, the use of quantitative data predominates in construction cost evaluation systems [17-19], on the other hand, most environmental assessment instruments have been adopting a qualitative approach $[20,21]$. In fact, budgets and cost systems are based on quantitative metrics (e.g., quantities of resources consumed, volumes of waste generated, time spent on activity) [22-24], beyond others project data and of their bill of quantities (BOQ) $[25,26]$. Meanwhile, environmental and sustainability systems often choose subjective criteria (e.g., expert assessment, scales of comparison) for selecting and excluding the indicators, their weights, and aggregation models, it toward to equate the different dimensions of sustainability (social, environmental and economic) [10,21].

In recent decades, new methodologies and systems have been proposed to reduce the subjectivity in the predictive models of the environmental impacts generated by the constructions. Chen et al., (2000) established a construction pollution index (CPI) to estimate the magnitude of the impacts in relation to the duration of construction activities foreseen in the construction schedule [27]. Gangolells et al., (2014) used data from the list of global enterprise quantities in the definition of a scale of weights to predict and compare environmental impacts $[21,28]$. In both systems, the quantitative data aim to increase the reliability of these models for supporting the decision process and evaluating the available constructive solutions and compare projects.

However, the large volume of data and concepts in multiple areas of knowledge may make it difficult to define the criteria for assessing and measuring the weights of each aspect [29]. A tool to address this issue are the so-called Decision support systems (DSS) [30]. The use of DSS, driven by computational advances, has grown in recent years, allowing their users to aggregate and analyze a large volume of data and information [29]. These analyses have been improving the evaluation and decision-making models for more environmentally-friendly products and processes. Applications of DDS in environmental management can be observed in applications that are related to urban development [29,31], occupational health and safety [32], construction waste management [33,34], and Geographic Information System (GIS) [35]. According to Kazak and Hoof [29], The DDS tools development should consider 3 keys aspects: (a) the ability to quantify features to reduce subjectivity and increase reliability; (b) the size of the potential results, according to the intended objective, ranging from the comparison within a finite set of choices to the use of open list to test solutions through an interactive process; and (c) the degree of uncertainty, considering the changes between the initial conditions and the implementation process.

In summary, the integration between cost bases and environmental performance assessment models can support to improve both tools in the decision-making process. Quantitative data from the cost bases reduce the subjectivity of environmental tools. At the same time, environmental indicators 
broaden the scope of the databases by adding sustainability criteria in the description of activities and allowing a comparison beyond the economic dimension in the choice and planning of activities.

Additionally, cost bases are widely used in construction practice, many of which are mandatory. The statistical data on consumption and productivity of these bases undergoes constant revision of the maintainer institution, including data collection directly from the productive sector. The cost bases are also present in most of the curricular content of courses such as civil engineering, production engineering, and architecture. Therefore, such a cost base can be a vehicle to disseminate environmental knowledge among construction workers and construction professionals.

In this context, the article carried out a mapping of environmental indicators in databases of costs to assess their ability to communicate and disseminate environmental information, and use in environmental control systems.

\section{Materials and Methods}

Figure 1 shows the workflow adopted in the research comprising three steps. The first step has mapped an overview of the applications of cost databases in the state of the art of environmental research and the state of the art of construction management. The second stage has implemented a matrix of assessment of the environmental communication on the cost databases. The final step has classified and analyzed the results, comparing the performance of each tool.

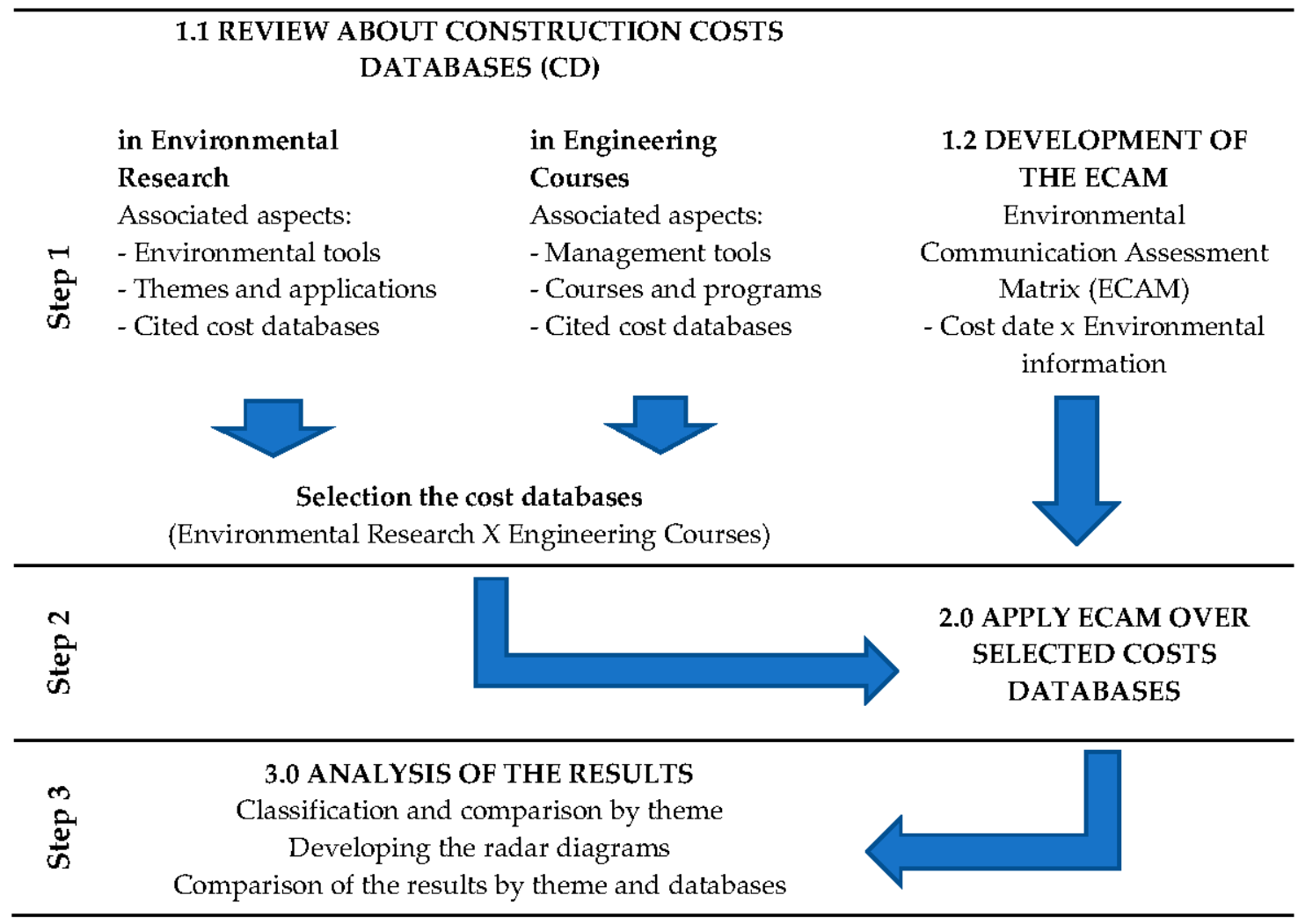

Figure 1. Research workflow. 
The analysis of the use of construction cost databases in environmental research have adopted a systematic literature review (RSL) of articles. The RSL classified and analyzed these articles by theme approached, research region, environmental tools used, the database of costs cited and what the application of these bases in the environmental study.

The survey of the Brazilian cost databases carried out a documental analysis in pedagogical projects of the engineering courses (PPC) and their programs, which were obtained in the electronic sites of the courses as described in Appendix A (Table A1). The search criterion was the occurrence of the following terms: cost database, construction costs or unit cost compositions. The data collection selected a sample of civil engineering course for each Brazilian state and the federal district, with the preference for courses in federal universities.

The selection of cost databases combined the results of the review of the state of the art and recognition of the construction sector [36]. The analysis of the literature has resulted in the selection of the international databases. In the selection of the national databases, the number of citations in the course projects analyzed prevailed.

An Environmental Communication Assessment Matrix (ECAM) was created to evaluate the cost databases performance (Table 1). The ECAM structure has intended to correlate the identified cost data with the degree of detail of the associated information. The variables were grouped into 5 themes: IC, information and communication; RW, resources consumption and waste generation; PS, public services demand; MP, machines demand and pollution generation; and, HS, occupational health and safety. The selection of these themes considered relevant environmental aspects from international regulations such as the Eco-Management and Audit Scheme (EMAS) [37] and scientific articles related to the evaluation of environmental aspects in construction $[21,27,38]$.

A scale of weights $(w)$ was defined to characterize the information quality of a cost data, varying from 0 to 2 according to the information can contribute to a better perception of the relation between the cost data and the environmental aspect: 0 , no information or low quality; 1, partial information; and 2, wide information.

The values assigned to the indicators were added to each of the 5 themes. Therefore, the overall score of each of the 5 themes S (S1, S2, S3, S4, and S5) was obtained by the following expression:

$$
S_{i}=\sum_{k=1}^{n} w_{k}
$$

where $S_{i}$ represents the value of environmental theme performance by each selected cost databases with the index $i$ ranging from 1 to 5 ( 5 themes); $w$ is the value adopted to characterize the quality of the environmental information of the data available from the cost databases with the index $k$ ranging according to the numbers of indicators by theme.

To compare the performance among the different analyzed cost bases, the values given by Equation (1) were normalized, obtaining the normalized scores for the 5 themes (S1, S2, S3, S4, and S5) according to the following equation:

$$
s_{i}=\frac{S_{i}}{S_{i, \max }}
$$

Finally, the overall value $(G)$ of the performance of each cost databases was obtained by summing the normalized values $\left(S_{i}\right)$ for the 5 themes according to the following equation:

$$
G=\sum_{i=1}^{5} s_{i}
$$


Table 1. Environmental Communication Assessment Matrix (ECAM) to Costs Databases.

\begin{tabular}{|c|c|c|c|}
\hline Theme (a)/Indicator (b) & $w=0$ (c) & $w=1$ & $w=2$ \\
\hline \multicolumn{4}{|c|}{ IC Information and Communication } \\
\hline IC1 user interface & press & web & web and software \\
\hline IC2 acquisition & annual license & $\begin{array}{l}\text { license limited (free) or } \\
\text { full (paid) }\end{array}$ & free no restrictions \\
\hline IC3 reported features & $\begin{array}{l}\text { consumption rate, } \\
\text { unitary compositions }\end{array}$ & $\begin{array}{l}\text { consumption rate, } \\
\text { unitary compositions, } \\
\text { and procedures }\end{array}$ & $\begin{array}{l}\text { consumption rate, unitary } \\
\text { compositions, procedures, } \\
\text { and specifications }\end{array}$ \\
\hline $\begin{array}{l}\text { IC4 parameterized } \\
\text { project }\end{array}$ & not provided & $\begin{array}{l}\text { construction size or } \\
\text { environmental } \\
\text { conditions }\end{array}$ & $\begin{array}{l}\text { construction size and } \\
\text { environmental conditions }\end{array}$ \\
\hline $\begin{array}{l}\text { IC5 parametrized } \\
\text { activities }\end{array}$ & not provided & $\begin{array}{l}\text { by materials or work } \\
\text { conditions }\end{array}$ & $\begin{array}{l}\text { by materials and work } \\
\text { conditions }\end{array}$ \\
\hline $\begin{array}{l}\text { IC } 6 \text { customization of } \\
\text { database }\end{array}$ & not provided & local prices & $\begin{array}{l}\text { local prices, new materials, } \\
\text { and new activities }\end{array}$ \\
\hline IC7 reported results & not provided & overall quantities & $\begin{array}{l}\text { overall quantities and } \\
\text { reports (e.g., Gantt diagram, } \\
\text { ABC curve) }\end{array}$ \\
\hline \multicolumn{4}{|c|}{ RW Resources consumption, and waste generation } \\
\hline $\begin{array}{l}\text { RW1 systems more } \\
\text { sustainable }\end{array}$ & not provided & some cases & $\begin{array}{l}\text { chapter of systems more } \\
\text { sustainable }\end{array}$ \\
\hline RW2 certificated wood & not informed & $\begin{array}{l}\text { informed in } \\
\text { specification }\end{array}$ & provide to selection \\
\hline RW3 recycled materials & not provided & concrete or aggregates & $\begin{array}{l}\text { concrete, aggregates and } \\
\text { others }\end{array}$ \\
\hline $\begin{array}{l}\text { RW4 other materials } \\
\text { more sustainable }\end{array}$ & not provided & some cases & $\begin{array}{l}\text { group of materials more } \\
\text { sustainable }\end{array}$ \\
\hline RW5 waste management & not provided & $\begin{array}{l}\text { only collection and } \\
\text { removal of waste }\end{array}$ & $\begin{array}{l}\text { waste management (control } \\
\text { of generation, separation } \\
\text { and collection) }\end{array}$ \\
\hline RW6 waste generated & not provided & estimate in percentage & $\begin{array}{l}\text { estimate by mass and } \\
\text { volume }\end{array}$ \\
\hline RW7 waste classification & not provided & not standardized & national standard \\
\hline \multicolumn{4}{|c|}{ PS Public services } \\
\hline $\begin{array}{l}\text { PS1 water consumption } \\
\text { for production }\end{array}$ & not provided & $\begin{array}{l}\text { estimated by } \\
\text { traditional services } \\
\text { except earthwork }\end{array}$ & $\begin{array}{l}\text { estimated by traditional } \\
\text { services and earthwork }\end{array}$ \\
\hline $\begin{array}{l}\text { PS2 water consumption } \\
\text { for workers }\end{array}$ & not provided & $\begin{array}{l}\text { estimated by } \\
\text { traditional services or } \\
\text { earthwork }\end{array}$ & $\begin{array}{l}\text { estimated by traditional } \\
\text { services and earthwork }\end{array}$ \\
\hline $\begin{array}{l}\text { PS3 electric energy } \\
\text { consumption }\end{array}$ & not provided & $\begin{array}{l}\text { estimated by services } \\
\text { except earthwork }\end{array}$ & $\begin{array}{l}\text { estimated by services and } \\
\text { earthwork }\end{array}$ \\
\hline \multicolumn{4}{|c|}{ MP Machinery, and pollution emissions } \\
\hline $\begin{array}{l}\text { MP1 circulation of } \\
\text { machinery and vehicles }\end{array}$ & not provided & $\begin{array}{l}\text { addressed in auxiliary } \\
\text { activity (productivity } \\
\text { by average distance) }\end{array}$ & $\begin{array}{l}\text { addressed in main activity } \\
\text { (productivity by average } \\
\text { distance) }\end{array}$ \\
\hline MP2 fuel consumption & not provided & $\begin{array}{l}\text { estimated by } \\
\text { earthwork services }\end{array}$ & $\begin{array}{l}\text { estimated by earthwork and } \\
\text { traditional services }\end{array}$ \\
\hline $\begin{array}{l}\text { MP3 noise/vibration } \\
\text { emission equipment }\end{array}$ & not provided & $\begin{array}{l}\text { informed but not } \\
\text { quantified }\end{array}$ & informed and quantified \\
\hline $\begin{array}{l}\text { MP4 noise level } \\
\text { information }\end{array}$ & not provided & $\begin{array}{l}\text { in the activity } \\
\text { description }\end{array}$ & $\begin{array}{l}\text { in the activity and the } \\
\text { control actions }\end{array}$ \\
\hline
\end{tabular}


Table 1. Cont.

\begin{tabular}{|c|c|c|c|}
\hline \multicolumn{4}{|c|}{ HS Health and safety } \\
\hline HS1 demands of workers & not informed & by activity & by activity and global \\
\hline $\begin{array}{l}\text { HS2 requirements for } \\
\text { occupational risks }\end{array}$ & not informed & $\begin{array}{l}\text { regulatory } \\
\text { requirements }\end{array}$ & $\begin{array}{l}\text { regulatory requirements, } \\
\text { and procedures }\end{array}$ \\
\hline $\begin{array}{l}\text { H3 classification of the } \\
\text { occupational risks }\end{array}$ & not informed & by type workers & $\begin{array}{l}\text { by workers type and } \\
\text { exposed risk }\end{array}$ \\
\hline
\end{tabular}

(a) selected themes adapted from EMAS, Chen et al., (2000) Gangolells et al., (2009), and Mateus; Bragança (2011).

(b) indicators during the construction phase. (c) Weight scale (w) adopted to characterize the quality of the environmental information of the data available on the cost databases, where $\mathbf{w}$ can be 0 (no information or low quality), 1 (partial information) and 2 (wide information).

\section{An Overview about Costs Databases}

In the LCC, one of the initial steps is to know the quantities of services and resources consumed in the construction process, as well as their externalities (e.g., losses, waste, emissions, nuisances). An important tool to support this process is the so-called construction cost database. Construction cost database brings together the sectoral data on the demand for resources, services, and workers for constructive activities, also considering productivity (workers and resources). Such cost databases also standardize this data, supporting the quantification of services and budgeting of buildings. In general, cost databases are used to determine the price of services and the elaboration of construction budgets based on resource consumption rates (including losses) by activity and the quantitative list of activities from the project $[22,24,39,40]$.

\subsection{Applications of the Construction Cost Databases in Environmental Aspect Assessment}

Table 2 presents a summary of the results of the literature review, by subject and environmental aspect, the environmental analysis method, cost databases, and their applications in the select study.

According to Table 2, the cost bases are present in studies of diverse environmental themes, such as waste generation, evaluation of construction materials, energy use, emission of pollution, water demand, occupational hazards and comparison among of constructive practices aiming at less impact. Figure 2 shows a cut-out of the analysis applied to the selected references. The cost databases have different applications and interact with environmental studies through different themes, materials, and methods.

Table 2. Applications of cost databases on environmental literature.

\begin{tabular}{|c|c|c|c|c|}
\hline Reference & Theme (Aspect) & Method & Database & $\begin{array}{c}\text { Application of the Cost } \\
\text { Databases }\end{array}$ \\
\hline [7] & $\begin{array}{l}\text { CDW (estimate in } \\
\text { urban infrastructure } \\
\text { projects) }\end{array}$ & $\begin{array}{l}\text { LCA. LCC. Design } \\
\text { optimization }\end{array}$ & $\begin{array}{l}\text { TCPO, ORSE, } \\
\text { SINAPI }\end{array}$ & $\begin{array}{l}\text { Identification of the } \\
\text { construction systems } \\
\text { and waste generated } \\
\text { based on the budget. }\end{array}$ \\
\hline [41] & $\begin{array}{l}\text { CDW (on-site } \\
\text { generation } \\
\text { indicators) }\end{array}$ & $\begin{array}{l}\text { Estimate for } \\
\text { mass/area. Units } \\
\text { Equalization }\end{array}$ & GP CYPE & $\begin{array}{l}\text { Estimate amount of } \\
\text { CDW per built area. }\end{array}$ \\
\hline [42] & $\begin{array}{l}\text { CDW (estimate on } \\
\text { the design stage) }\end{array}$ & $\begin{array}{l}\text { LCA. Units } \\
\text { Equalization. }\end{array}$ & BCCA & $\begin{array}{l}\text { Estimate waste and loss } \\
\text { during construction }\end{array}$ \\
\hline [43] & $\begin{array}{l}\text { CDW (quantification } \\
\text { and management) }\end{array}$ & $\begin{array}{l}\text { BOQ. Units } \\
\text { Equalization. }\end{array}$ & BCCA & $\begin{array}{l}\text { Estimate CDW per } \\
\text { service unit. }\end{array}$ \\
\hline [44] & $\begin{array}{l}\text { Environmental } \\
\text { impacts of building } \\
\text { materials }\end{array}$ & $\begin{array}{l}\text { LCA. Case study. } \\
\text { Material and } \\
\text { energy flow. }\end{array}$ & TCPO, SimaPro & $\begin{array}{l}\text { Identification of the } \\
\text { inputs and outputs flow. } \\
\text { Estimate materials } \\
\text { consumption per service } \\
\text { unit. }\end{array}$ \\
\hline
\end{tabular}


Table 2. Cont.

\begin{tabular}{|c|c|c|c|c|}
\hline [45] & $\begin{array}{l}\text { Environmental } \\
\text { impacts of building } \\
\text { materials }\end{array}$ & LCA. Case Study. & TCPO, SimaPro & $\begin{array}{l}\text { Estimate materials } \\
\text { consumption per service } \\
\text { unit }\end{array}$ \\
\hline [46] & $\begin{array}{l}\text { Water footprint } \\
\text { (estimate on the } \\
\text { construction) }\end{array}$ & $\begin{array}{l}\text { Curve ABC. } \\
\text { Gantt Chart. }\end{array}$ & TCPO & $\begin{array}{l}\text { Estimate the water } \\
\text { consumption per service } \\
\text { to determine the water } \\
\text { footprint in construction } \\
\text { processes }\end{array}$ \\
\hline [47] & $\begin{array}{l}\text { Environmental } \\
\text { impacts of } \\
\text { construction systems }\end{array}$ & LCA & $\begin{array}{l}\text { SINAPI, SimaPro, } \\
\text { Ecoinvent }\end{array}$ & $\begin{array}{l}\text { Identification of the } \\
\text { inputs and outputs flow. } \\
\text { Estimate materials } \\
\text { consumption per service } \\
\text { unit. }\end{array}$ \\
\hline [48] & $\begin{array}{l}\text { On-Site } \\
\text { Environmental } \\
\text { Impacts and Health } \\
\text { and Safety Risk }\end{array}$ & $\begin{array}{l}\text { ISO 14001:2004 } \\
\text { OHSAS 18001:2007 }\end{array}$ & ITeC & $\begin{array}{l}\text { To Identify the work } \\
\text { sections in the } \\
\text { construction of } \\
\text { residential buildings }\end{array}$ \\
\hline [49] & $\begin{array}{l}\text { More sustainable } \\
\text { construction } \\
\text { (comparison of costs) }\end{array}$ & $\begin{array}{l}\text { CESSUC. Case } \\
\text { Study. }\end{array}$ & InterPro 2010 & $\begin{array}{l}\text { Estimate and comparing } \\
\text { the referential } \\
\text { construction costs about } \\
\text { more sustainable } \\
\text { constructions. }\end{array}$ \\
\hline [50] & $\begin{array}{l}\text { More sustainable } \\
\text { construction } \\
\text { (sustainable } \\
\text { practices) }\end{array}$ & LCA. MARS-H & Fichas by LNEC & $\begin{array}{l}\text { Quantification for } \\
\text { comparison between } \\
\text { traditional and more } \\
\text { sustainable construction }\end{array}$ \\
\hline [11] & $\begin{array}{l}\text { Energy retrofit of } \\
\text { historic buildings }\end{array}$ & $\begin{array}{l}\text { Cost optimally, } \\
\text { LCA and LCC }\end{array}$ & GP CYPE & $\begin{array}{l}\text { Getting of costs } \\
\text { (materials, systems, } \\
\text { operation, and } \\
\text { maintenance) to analyses } \\
\text { the cost optimality. }\end{array}$ \\
\hline [51] & $\begin{array}{l}\text { Energy and } \\
\text { Emissions Impact } \\
\text { (Housing) }\end{array}$ & $\begin{array}{l}\text { LCA. Emissions } \\
\text { balance. }\end{array}$ & $\begin{array}{l}\text { GP CYPE, LIDER + } \\
\text { CALENER. }\end{array}$ & $\begin{array}{l}\text { Estimate urbanization } \\
\text { and maintenance costs } \\
\text { generated from the } \\
\text { housing projects }\end{array}$ \\
\hline [6] & $\begin{array}{l}\text { Energy Efficiency } \\
\text { and Carbon } \\
\text { emissions (news } \\
\text { buildings) }\end{array}$ & $\begin{array}{l}\text { LCA. LCC. } \\
\text { Integrated design }\end{array}$ & RS Means & $\begin{array}{l}\text { Estimate the cost } \\
\text { implications of } \\
\text { energy-based carbon } \\
\text { emissions }\end{array}$ \\
\hline [15] & $\begin{array}{l}\text { Energy Efficiency } \\
\text { and Carbon } \\
\text { emissions (building } \\
\text { renovation) }\end{array}$ & $\begin{array}{l}\text { LCC. Annex } 56 \text { by } \\
\text { IEA EBC. }\end{array}$ & GP CYPE & $\begin{array}{l}\text { Estimate of the } \\
\text { investment, } \\
\text { maintenance, and } \\
\text { replacement costs in } \\
\text { building renovation }\end{array}$ \\
\hline
\end{tabular}

Notes: (a) Themes: Construction and Demolition Waste (CDW). (b) Methods: Life Cycle Assessment (LCA), Life Cycle Cost (LCC), Bill of Quantities (BOQ), Método de Evaluación de la Vivienda Sustentable (CESSUC); Metodologia de Avaliação Relativa da Sustentabilidade de Edifícios de Habitação (MARS-H); International Energy Agency Energy in Buildings and Communities (IEA EBC). (c) Databases: Tabela de Composições de Preço (TCPO); o Sistema Nacional de Pesquisa de Custos e Índices da Construção Civil (SINAPI)—SINAPI e o Sistema de Orçamento de Obras de Sergipe (ORSE); Gerador de Preços CYPE (GP CYPE); Base de Costes de la Construcción de Andalucía (BCCA); Laboratório Nacional de Engenharia Civil (LNEC); Calificación Energética para Vivienda y Pequeños Edificios Terciarios (CALENER VYP); Limitación de Demanda Energética (LIDER). 


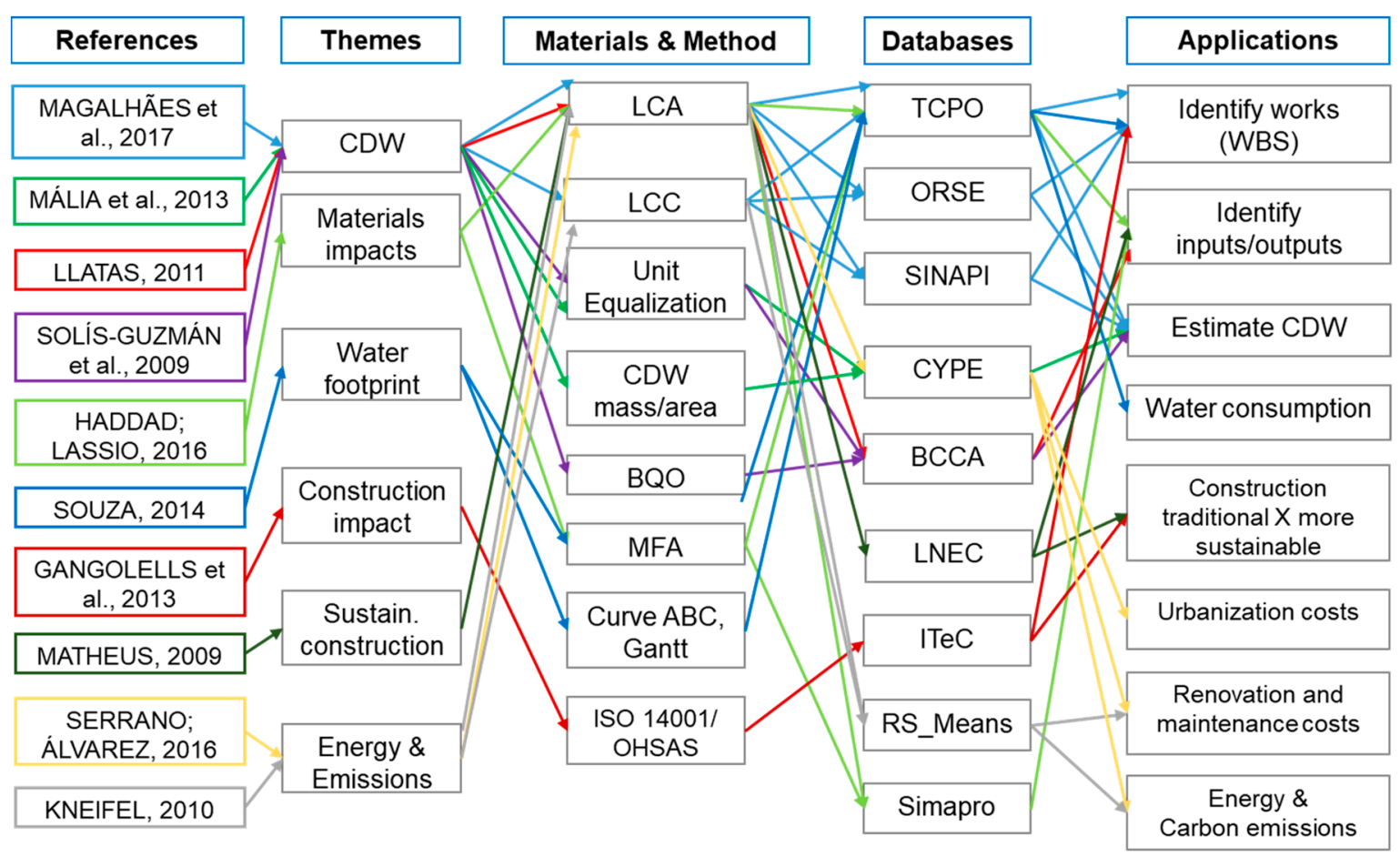

Figure 2. Network of correlations between Themes, Materials and Methods, Databases and their Applications by analyzed articles.

These costs databases served as a source for the acquisition of quantitative data from constructive services or for description and qualitative analysis of the stages during the construction process. In the first case, the quantitative data obtained include the average consumption of resources (materials and services) and the estimation of losses and generation of construction and demolition waste (CDW) $[7,41,42,52]$. This estimate uses as an initial reference the provided budget and the description of its bills of quantities (BOQ) and applies over these the rates of the cost bases for consumption of resources and generation of waste per unit of service. In the second case, environmental studies use the structure of the unit compositions to identify the activities involved and to analyze the process flow (e.g., inputs/outputs, mass/energy). Among the themes in this group, the evaluation of the sustainability of the materials used $[44,45]$, the comparison of construction systems and the proposition of more sustainable practices $[49,50]$ as well as pollution emission and energy efficiency $[11,15,51]$ can be considered.

The scope of the analysis depends on the steps addressed and the degree of detail in the description of the activities involved. Thus, the study can range from a specific stage to the entire life cycle of the built environment (construction, operation, maintenance, and deconstruction). In the case of carbon emissions, for example, some references address the stage of use of the building [6], while others refer to the construction process (from the preparation of the site to transportation and disposal of waste) [51].

The studies involving databases in Table 2 have applied different environmental assessments methods, some recurring in sustainability analysis such as life-cycle analysis, material flow analysis, and mass and energy balance. To a lesser extent, the use of more recent methodologies such as the Methodology for the Relative Sustainability Assessment of Residential Buildings-MARS-H $[50,53]$ or Calificación Energética para Vivienda y Pequeños Edificios Terciarios (CALENER VYP) [51].

The structure and data extracted from the compositions of the cost databases support the description of activities and the quantification of their inputs and outputs in the studies with Material Flow Analysis (MFA) [54] and Material Input per unit of Service (MIPS) [36]. 
In addition to the cited scientific articles, sustainability guides and certification system also adopt cost databases to estimate losses and generation of construction waste. For example, material loss and productivity data from TCPO are present in the Casa Selo Azul certification of Caixa Econômica Federal [55] and waste generation data from GP CYPE are cited in the Best Environmental Management practice for the building and construction sector by Institute Prospective Technological Studies of the European Union [2].

Management tools often associated with the cost databases use are also shown in Table 2, such as Bills of Quantities [43], Gantt Chart and ABC Curve [46], and Material Flow Analysis [44].

Among the tools and cost databases are international databases, national and regional bases from different countries. While databases such as CYPE and RM Means have applications in several countries, others have national applications as a database of the Institute of Technology of Catalonia (BEDEC ITeC) [56], Base of Costs of the Construction of Andalusia (BCCA) [23] and Base of Prices of the Construction of the Community of Madrid-BCC [57] in Spain and the Fichas de rendimento by National Laboratory for Civil Engineering of Portugal (LNEC) [58].

In the Brazilian construction market, national and regional cost databases were cited [7,44-47], the Price Composition Table (TCPO) [24] and the National System of Cost and Construction Indexes Survey (SINAPI) [39], as well as a regional base, the Construction Budget System Sergipe (ORSE) [59], which has also been applied in other regions in studies and comparative studies [60].

Cross-analysis between the environmental concepts and tools versus traditional tools in construction management practices highlights the importance of bringing practice and environmental theory closer to construction activities, thereby increasing the reliability of results and identifying ways to reduce impacts of the construction process.

\subsection{Use of Cost Bases into the Engineering Course Curriculums in Brazil}

The documentary analysis identified only three construction cost databases in the 27 engineering courses analyzed, as described in Appendix B (Table A2). According to the findings, the Table of Compositions of Prices for Budgets (TCPO) is present in 21 of the 27 courses analyzed (78\%), significantly higher than those for the National System of Costs Survey and Indexes of Civil Construction (SINAPI) cited by only 4 courses $(11 \%)$ and the System of Referential Costs of Works (SICRO), 3 courses (7\%).

In the course programs, such cost databases are associated with different themes and concepts (Table 3). Those subjects directly related to building budgets are among the most cited, such as the concepts of cost composition with 85\%, and the direct and indirect costs (acronym BDI in Portuguese) with $67 \%$. Nevertheless, the Basic Unit Cost (acronym CUB in Portuguese), an important sectoral indicator in Brazil, was found in only two courses, at the Federal University of Piaui (UFPI) and at the Federal University of Pampa (UNIPAMPA).

More broadly, cost databases are also used as a source of support for traditional construction planning and management tools. Among these techniques and tools, the most cited were the physical-financial schedule (85\%), the analysis of interdependencies by PERT/CPM networks $(67 \%)$, the use of resources by the ABC Curve (41\%), the aggregation of costs over time by the $\mathrm{S}$ curve $(33 \%)$, the analysis of the leveling of activities through the line-of-balance technique (33\%), and the Gantt chart (26\%) (Table 3$)$.

Contrary to findings have observed in the literature review, in the programs and courses analyzed, few associations were found between environmental themes and cost databases, restricted to waste management in the course of the Federal Institute of Pernambuco (IFPE) and the evaluation of life-cycle costs in in the course of the Federal Institute of Paraiba (IFPB) (Table 3). 
Table 3. Themes and concepts associated with the use of cost databases in the selected courses.

\begin{tabular}{|c|c|c|}
\hline Themes and Concepts & Records & $\%$ \\
\hline \multicolumn{3}{|l|}{ (a) Budget-related concept and indexes } \\
\hline Compositions of unit costs & 24 & $89 \%$ \\
\hline Bonus and Indirect Costs (BDI acronym in Portuguese) & 18 & $67 \%$ \\
\hline Basic Unit Cost (CUB acronym in Portuguese) (in UFPI, UFMT and UNIPAMPA) & 3 & $11 \%$ \\
\hline \multicolumn{3}{|l|}{ (b) Management-related techniques and tools } \\
\hline Physical-financial schedule & 23 & $85 \%$ \\
\hline PERT/CPM & 18 & $67 \%$ \\
\hline ABC-Curve & 11 & $41 \%$ \\
\hline S-Curve & 9 & $33 \%$ \\
\hline Line of Balance (LOB) & 9 & $33 \%$ \\
\hline Gantt Chart & 7 & $26 \%$ \\
\hline \multicolumn{3}{|l|}{ (c) Other themes } \\
\hline Construction-site layout & 6 & $22 \%$ \\
\hline Lean construction (in UFAL, UFES and, UFMG) & 3 & $11 \%$ \\
\hline Waste management (in IFPE) & 1 & $4 \%$ \\
\hline Life-cycle cost assessment (in IFPB) & 1 & $4 \%$ \\
\hline
\end{tabular}

The survey identified many disciplines in which their course program contains the construction cost bases. Table 4 presents these disciplines grouped into three main areas: (a) management and planning; (b) project; (c) budget; and; (d) construction technologies.

Table 4. Courses whose programs refer to the cost databases.

\begin{tabular}{|c|c|c|c|}
\hline Subject & Courses & Records & $\%$ \\
\hline \multirow[t]{4}{*}{ Management and Planning } & $\begin{array}{l}\text { Construction planning. Construction management. } \\
\text { Planning and control of works. Planning and } \\
\text { construction management. }\end{array}$ & 18 & $74 \%$ \\
\hline & Production control. Control of the construction process & 8 & $30 \%$ \\
\hline & Quality of Construction (in UFMS and UFG) & 2 & $7 \%$ \\
\hline & Construction loss control (in UFPI) & 1 & $4 \%$ \\
\hline Design & $\begin{array}{l}\text { Civil Construction Project. Design of Buildings I. Project } \\
\text { management (in UFC and UFRJ) }\end{array}$ & 2 & $7 \%$ \\
\hline Budgeting and LCC & $\begin{array}{l}\text { Budget in construction. Costs management. } \\
\text { Specifications and budgets. }\end{array}$ & 13 & $48 \%$ \\
\hline \multirow{2}{*}{ Construction Technology } & Construction I and II. Construction of building I and II. & 13 & $48 \%$ \\
\hline & Technology of construction I and II. & 7 & $26 \%$ \\
\hline
\end{tabular}

Notes: Federal University of Mato Grosso (UFMT); Federal University of Goias (UFG); Federal University of Piaui (UFPI); Federal University of Ceara (UFC); Federal University of Rio de Janeiro (UFRJ). Source: Documentary analysis of Pedagogical Projects of Courses-PPC (Authors, 2018).

To a lesser degree, some programs of transport courses also cite cost concepts and cost databases. the discipline Roads, these databases are often related to the stages and materials that comprise the execution of the construction services, as in the programs of the engineering course of the University of Brasília (UNB), Federal University of Amazonas (UFAM), Federal Institute of Rondonia), Federal University of Espirito Santo (UFES) and Federal University of Pampa (UNIPAMPA) in Rio Grande do Sul. In other cases, the contents were limited to the geometric design of the tracks, such as the Federal University of Goias (UFG), Federal University of Tocantins (UFT), Federal University of Santana Catarina (UFSC), Federal University of Piaui Federal University of Pernambuco (IFPE). 
The analysis of the course programs (Table 4) also verified that they have a set of bibliographical references in common on subjects such as budget, management, and technology of the construction. Table 5 shows the top ten books, all related to the construction costs theme; these books have a strong influence on the education of Brazilian engineers and their practices.

Table 5. 10 Most cited books in the course program related to cost databases.

\begin{tabular}{lcc}
\hline \multicolumn{1}{c}{ Authors and Book (in Portuguese) } & Records & $\%$ \\
\hline LIMMER, C V. Planning, budgeting and control of projects and works [61]. & 22 & $81 \%$ \\
YAZIGI, Walid. The technique of building [62]. & 15 & $56 \%$ \\
TISAKA, M. Budget in construction: consulting, project and execution [63]. & 13 & $48 \%$ \\
BERNARDES, M. Production control planning for construction companies [64]. & 12 & $44 \%$ \\
GOLDMAN, Pedrinho. Introduction to planning and cost control in Brazilian civil & 10 & $37 \%$ \\
construction [65]. & 10 & $37 \%$ \\
MATTOS, A. D. How to prepare construction budgets [66]. & 9 & $33 \%$ \\
MATTOS, A. D. Planning and control of construction [67]. & 9 & $33 \%$ \\
GIAMUSSO, S. E. Budget and Costs in Construction [68]. & 8 & $30 \%$ \\
DIAS, Paulo R. V. Cost engineering: a budgeting methodology for civil constructions [69]. & 7 & $26 \%$ \\
GUEDES, Milber F. Caderno de encargos (title in Portuguese) [70]. & 7
\end{tabular}

Source: Documentary analysis of Pedagogical Projects of Courses-PPC (Authors, 2018).

\subsection{Selection of Cost Databases Considering the State of Art and the State of Technic}

According to the criteria established in the analysis of the research (Figure 1) (i.e., cross-analysis between the cost data bases most cited in the bibliographic review and the documental analysis of the course projects), six cost databases were selected for analysis (three international and three national). Figure 3 shows the flow adopted for the selection of databases and their main characteristics.

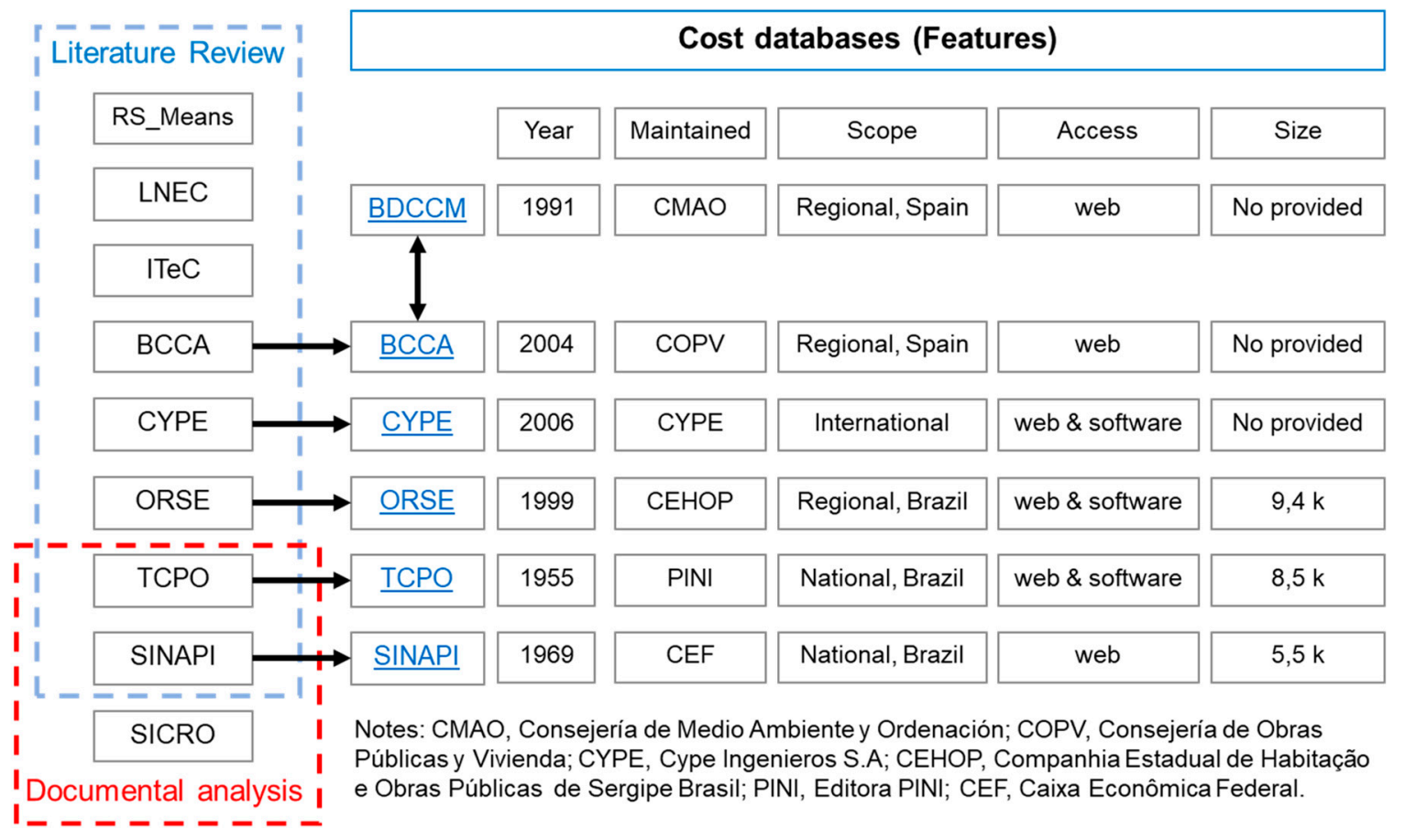

Figure 3. Databases selected and their main characteristics (Authors, 2018). 
The first group brought together three Brazilian databases: Table of Price Compositions and Budgets (TCPO); National System of Research of Costs and Indices of the Civil Construction (SINAPI), and the System of Budget of Works of Sergipe (ORSE). The second group brought together three international bases: Generator of Price by CYPE; Base of Costs of the Construction of Andalusia(BCCA) [23]; e Base of Prices of the Construction of the Community of Madrid [57].

(a) Selected Brazilian cost databases - SINAPI, TCPO and ORSE-SINAPI, TCPO e ORSE

TCPO and SINAPI are considered the main bases of national coverage $[44,45,71]$ while the ORSE is a base that has recently expanded its area of operation $[7,60]$.

TCPO commercial database was launched by the PNI publisher in 1955, inspired by Master Format classification which is adopted in the United States and Canada [24] and currently presents a structure in five levels: division, subdivision, nature of the item, type and finally the item itself. The subdivision code describes the construction system, while the nature code describes whether the item is related to labor, material, equipment, financial costs or services [24]. TCPO brings together two databases (Buildings and Infrastructure) with more than 8500 unitary service compositions.

SINAPI is a public system of costs and indices of the construction industry. It was created in 1969 and has been maintained by Caixa Econômica Federal (CEF) and updated with prices collected by the Brazilian Institute of Geography and Statistics (IBGE) in the 27 federation units [39,60]. The SINAPI prices are a mandatory reference for budgeting and contracting of public works with resources of the Union in Brazil [72], including offering reference budgets for recurrent typologies in the construction sector.

The ORSE was developed by the State Housing and Public Works Company of Sergipe (CEHOP) and by the Sergipe Sanitation Company (DESO) [7,60,73]. According to its website, currently, the system has 9626 inputs and 9445 compositions registered for service prices [74].

(b) Selected international cost systems-CYPE, BCCA and BDCCM.

The Price Generator (GP CYPE) is a commercial cost database maintained by Cype Ingenieros [22] with versions adapted for 27 countries. The database assembles information on inputs and activities regarding pricing, construction techniques, waste generated, $\mathrm{CO}_{2}$ emissions, maintenance and operational risks [22]. The study chose the Brazilian version which presents data for three types of works: New Constructions, Reforms, and Infrastructure.

The Base of Costs of the Construction of Andalusia (BCCA) is maintained by Consejería de Obras Públicas y Vivienda (COPV) and Consejo Andaluz de Colegios de Aparejadores y Arquitectos Técnicos [43]. The BCCA, created in 2004, is a result of the systematization and classification of construction works in the region of Andalusia, action begun in 1884 by Fundación Codificación y Banco de Precios de la Construcción (FCBP) through the first Classification System [75]. The BCCA basic price classification comprises families and subfamilies.

The Base of Prices of the Construction of the Community of Madrid (BDCCM) was launched in 1991 and is periodically reassessed [57]. Its latest version was released in 2007 by Dirección General de Arquitectura y Vivienda de la Consejería de Medio Ambiente y Ordenación.

\section{Results and Discussion about Costs Databases Assessment}

\subsection{The System of Classification and Quantification of Cost Bases}

In general, the analyzed databases presented structures at hierarchical levels and descriptors to facilitate the consultation and editing, where their compositions can be accessed in block or individually. Such compositions are organized in steps (e.g., worksite preparation, foundations, structure, fence, installations and finish) which bring together similar building systems. In this sense, the BDCCM has a structure in four levels: area, chapter, subchapter, and group [57]. In turn, TCPO is structured in five levels: division, subdivision, nature of the item, type, and item [24]. Each TCPO composition has an individual coding, where the initial sequence represents the phase and the constructive system, 
and the next sequence indicates the labor, material, equipment, financial costs or activities. Among the building information classification systems adopted can be cited the Andalusia Construction Costs Database by the BCCA [76], the Normas Tecnológicas de la Edificación (NTE) by BDCCM [57] and the MasterFormat that served as the basis for TCPO [24].

The internal hierarchy of these systems of classification of works and services are directly related to the work breakdown structure (WBS). Thus, as observed in the review, the analytical budget generated according to these cost databases can also be used as a source to identify the constructive phases and the flow of materials and services (inputs and outputs) [7,44,45,77].

The productive resources can be inputs, machines, services, and labor. The indicators are used to qualify and quantify inputs and labor (description, unit of measure and cost), compositions (description, application, unit of measure and coefficients of consumption and labor) and expenses (direct or indirect). However, the wide variety of inputs and services regarding the nature and method of quantification makes aggregation and comparison difficult in environmental studies, for example, the quantification of inputs and outputs for mass and energy balance. This difficulty is partially circumvented through the adoption of equalization techniques when possible as can be observed in some of the cited articles of the review [41-43].

\subsection{Findings from the Evaluation of Cost Bases}

Table 6 presents the results of the environmental communication assessment matrix of the cost databases by themes and aspects (Table 1), Equations (1) and (2).

Table 6. Results of the environmental communication assessment matrix (Authors, 2018).

\begin{tabular}{ccccccc}
\hline Information and Communication & TCPO & SINAPI & ORSE & CYPE & BCCA & BDCCM \\
\hline user interface & 2 & 1 & 1 & 2 & 0 & 1 \\
acquisition & 0 & 2 & 2 & 2 & 2 & 2 \\
reported features & 2 & 0 & 2 & 2 & 1 & 1 \\
parameterized project & 0 & 0 & 0 & 2 & 0 & 2 \\
parametrized activities & 2 & 0 & 2 & 2 & 0 & 0 \\
customization of database & 2 & 0 & 2 & 2 & 0 & 1 \\
reported results & 2 & 0 & 2 & 2 & 0 & 0 \\
Score (S1) & $\mathbf{1 0}$ & $\mathbf{3}$ & $\mathbf{1 1}$ & $\mathbf{1 4}$ & $\mathbf{3}$ & $\mathbf{7}$ \\
Maximum score possible & 14 & 14 & 14 & 14 & 14 & 14 \\
Standard score (s1) & $\mathbf{0 . 7}$ & $\mathbf{0 . 2}$ & $\mathbf{0 . 8}$ & $\mathbf{1 . 0}$ & $\mathbf{0 . 2}$ & $\mathbf{0 . 5}$ \\
\hline Resources Consumption and Waste Generation & TCPO & SINAPI & $\mathbf{O R S E}$ & $\mathbf{C Y P E}$ & $\mathbf{B C C A}$ & $\mathbf{B D C C M}$ \\
\hline systems more sustainable & 1 & 0 & 1 & 2 & 1 & 2 \\
certificated wood & 0 & 0 & 0 & 0 & 0 & 0 \\
recycled materials & 1 & 0 & 1 & 1 & 1 & 1 \\
other materials more sustainable & 1 & 0 & 1 & 2 & 1 & 2 \\
CDW management (services) & 1 & 1 & 1 & 2 & 2 & 1 \\
CDW generated & 1 & 0 & 1 & 2 & 1 & 1 \\
CDW classification & 0 & 0 & 0 & 2 & 0 & 0 \\
Score (S2) & $\mathbf{5}$ & $\mathbf{1}$ & $\mathbf{5}$ & $\mathbf{1 1}$ & $\mathbf{6}$ & $\mathbf{7}$
\end{tabular}


Table 6. Cont.

\begin{tabular}{ccccccc}
\hline Water and Energy Consumption & TCPO & SINAPI & ORSE & CYPE & BCCA & BDCCM \\
\hline water consumption for production & 0 & 0 & 0 & 1 & 2 & 1 \\
water consumption for workers & 0 & 0 & 0 & 0 & 0 & 0 \\
electric energy consumption & 0 & 0 & 0 & 0 & 0 & 0 \\
Score (S3) & $\mathbf{0}$ & $\mathbf{0}$ & $\mathbf{0}$ & $\mathbf{1}$ & $\mathbf{2}$ & $\mathbf{1}$ \\
Maximum score possible & 6 & 6 & 6 & 6 & 6 & 6 \\
Standard score (s3) & $\mathbf{0 . 0}$ & $\mathbf{0 . 0}$ & $\mathbf{0 . 0}$ & $\mathbf{0 . 2}$ & $\mathbf{0 . 3}$ & $\mathbf{0 . 2}$ \\
\hline Machinery Circulation and Pollution Emissions & TCPO & SINAPI & ORSE & $\mathbf{C Y P E}$ & $\mathbf{B C C A}$ & $\mathbf{B D C C M}$ \\
\hline circulation of machinery and vehicles & 1 & 1 & 1 & 1 & 1 & 1 \\
fuel consumption & 1 & 1 & 0 & 0 & 0 & 0 \\
noise/vibration emission equipment & 2 & 2 & 2 & 2 & 2 & 2 \\
noise level information & 0 & 0 & 0 & 0 & 0 & 0 \\
Score (S4) & $\mathbf{4}$ & $\mathbf{4}$ & $\mathbf{3}$ & $\mathbf{3}$ & $\mathbf{3}$ & $\mathbf{3}$ \\
Maximum score possible & 8 & 8 & 8 & 8 & 8 & 8 \\
Standard score (s4) & $\mathbf{0 . 5}$ & $\mathbf{0 . 5}$ & $\mathbf{0 . 4}$ & $\mathbf{0 . 4}$ & $\mathbf{0 . 4}$ & $\mathbf{0 . 4}$ \\
\hline Health and Safety & TCPO & $\mathbf{S I N A P I}$ & $\mathbf{O R S E}$ & $\mathbf{C Y P E}$ & $\mathbf{B C C A}$ & $\mathbf{B D C C M}$ \\
\hline Demand of workers & 2 & 1 & 2 & 2 & 1 & 1 \\
requirements for occupational risks & 2 & 0 & 2 & 2 & 0 & 0 \\
classification of the occupational risks & 0 & 0 & 0 & 0 & 0 & 0 \\
Score (S5) & $\mathbf{4}$ & $\mathbf{1}$ & $\mathbf{4}$ & $\mathbf{4}$ & $\mathbf{1}$ & $\mathbf{1}$ \\
Maximum score possible & 6 & 6 & 6 & 6 & 6 & 6 \\
Standard score (s5) & $\mathbf{0 . 7}$ & $\mathbf{0 . 2}$ & $\mathbf{0 . 7}$ & $\mathbf{0 . 7}$ & $\mathbf{0 . 2}$ & $\mathbf{0 . 2}$ \\
\hline
\end{tabular}

Figure 4 shows the standard results from the environmental communication performance evaluation model over the cost databases, as described in Table 6. To facilitate comparisons, radar diagrams for global values have been developed for each of the themes covered.

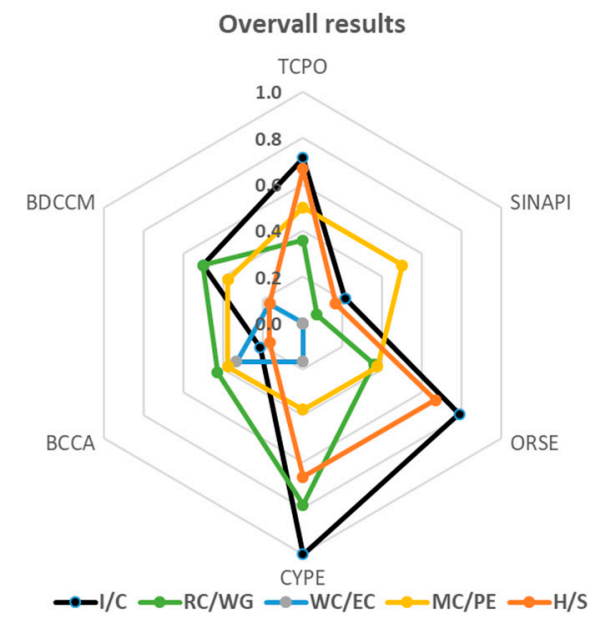

(a)

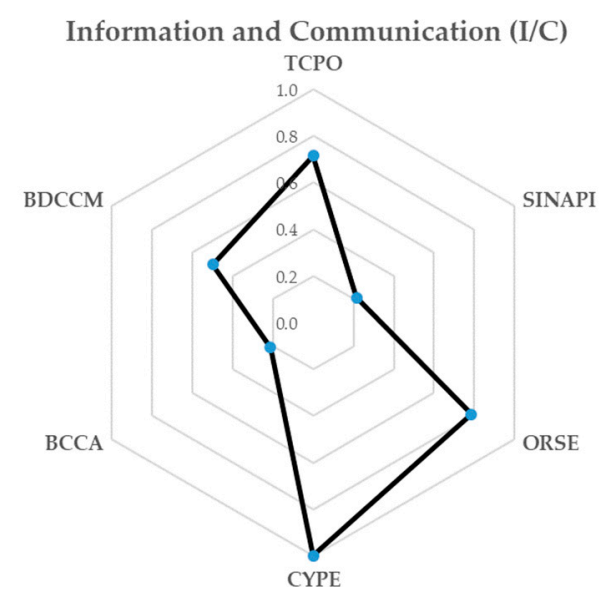

(b)

Figure 4. Cont. 


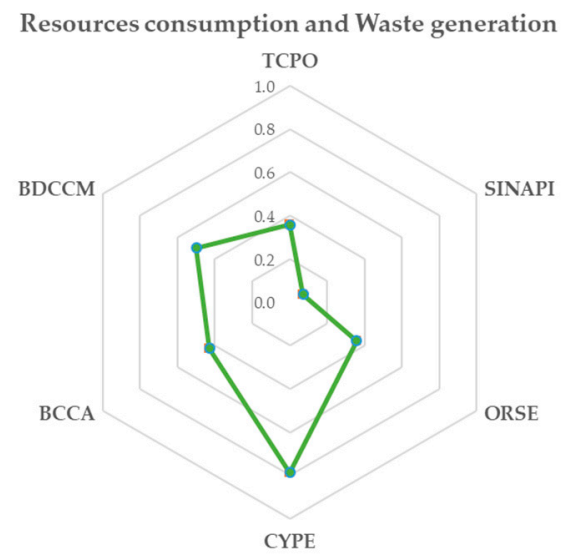

(c)

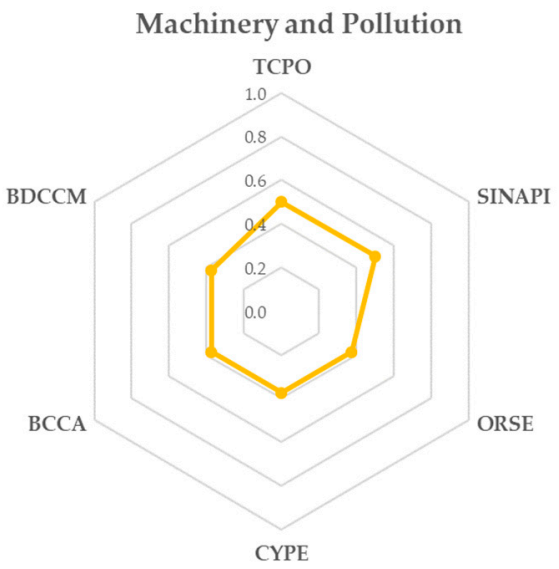

(e)

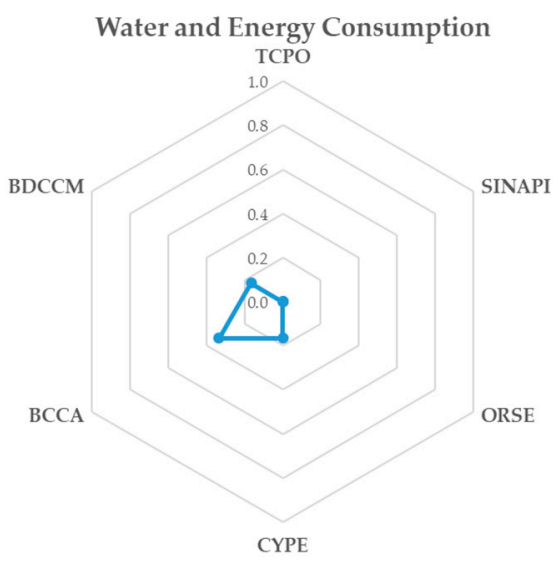

(d)

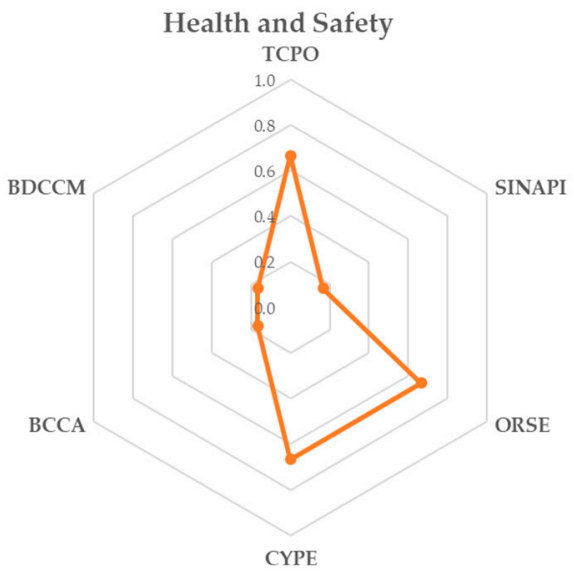

(f)

Figure 4. Performance of cost databases by the Environmental Communication Assessment Matrix. Description of radar diagrams by themes: (a) overall result about 5 themes; (b) information and communication; (c) resources consumption and waste generation; (d) water and energy consumption; (e) machinery and pollution; (f) health and safety.

\subsection{Interface (Information and Customization)}

The six databases are similar in the records classification model and access through electronic sites. However, these same databases present significant differences in some features (e.g., database size, user interface, and communication of the results).

The analysis of the way in which the platform (interface) of the databases can help in the information management and environmental communication used adapted parameters of the PDCA cycle, it traditional in the evaluation of construction projects [78]. Thus, it was evaluated how the computerized systems and their data and information could contribute to the planning, application, control, and performance in the construction process. Some databases have an integrated computerized system for accessing their records and customizing information entries and exit. In these cases, the manipulation is through of a proprietary software (TCPO and ORSE) or directly in its electronic site (BDCCM). In other databases, the data is summarized in analytical compositions available only in a text file (BCCA) or worksheet (SINAPI) compatible with commercial electronic spreadsheets (e.g., Microsoft Excel).

Moreover, some electronic sites provide auxiliary documents which describe the methodology and classification system. For example, TCPO, ORSE and GP CYPE provide guidance on regulatory references, control procedures and measurement criteria. These regulations and control criteria are limited to issues of quality and safety and occupational health, these ignoring environmental impacts and annoyances generated. Those with computerized systems allow for some level of customization 
of their database (e.g., features of the enterprise, add new materials, change and create compositions). In the GP CYPE, the user can adjust the characteristics of the construction through the information such as built area, area and number of floors, accessibility and topography conditions, project type (e.g., single family, multifamily), distance to the licensed area for waste disposal, in addition to choosing between 20 types of plant geometry and land occupation.

Some of the systems (TCPO, ORSE and GP CYPE) present a set of construction management tools to support the planning and monitoring of services, tools such as the ABC curve, Gantt chart, and financial physical schedule. SINAPI and BBCA, in turn, do not allow the manipulation of data, only the consultation via an electronic website of the documents describing the service compositions, the methodology (memory), the systematic classification and the price updates collected.

\subsection{Resources and Waste}

In the selected cost databases, the productive resources comprise items such as materials, construction personnel, and equipment. In the service unit compositions, the concept of consumption adopted is the sum of the theoretical quantity needed for each resource plus the losses along the construction process (acquisition, stock, application) $[24,60]$ related to local productivity. This quantity (theoretical and losses) defines the coefficient of consumption per service unit.

The BCCA adopts coefficients of consumption and productivity rates. The other bases (TCPO, ORSE, GP CYPE and BDCCM) allow the choice of consumption and productivity scales. This choice is in agreement with the concept of variable productivity $[24,66,79]$, but limited to the economic dimension. Such an approach could be extended to the concept of environmental performance, which also influenced by productive factors (available technologies, staff qualification, and control systems). In the current model, the productivity range concept allows for estimating economic indicators (costs and time); however, it still does not allow to identify this variation about environmental aspects.

In the database structure, the traditional construction systems and materials, many of them with low environmental performance, are still prevalent, it is addressing the environmental and low impact materials only in isolated cases. In TCPO, for example, materials associated with occupational hazards such as asbestos cement tiles and pipes are listed. Only one chapter among the 17 BCCA addresses environmental services. Even this chapter (Waste Management) does not address the reduction or control of generation, limiting itself to an end-of-pipe control of waste removal: (a) metals, (b) asphalts and tarpaulins, (c) concrete, ceramics, and plaster. In the other bases (TCPO, SINAPI, ORSE, and BDCCM), no chapter was identified to gather such environmental services, those activities such as the removal of waste generated during land clearing or demolition are included in the Preliminary Services stage.

Only CYPE incorporates some system to classify the waste, using a national legal landmarks, Resolution 307 of 2002 by Brazilian National Council of Environment (CONAMA) [80] and Instruction $\mathrm{n}^{\circ} 13$ by Brazilian Institute of Environment and Renewable Natural Resources (IBAMA) [81] besides estimating the mass and volume generated.

Even in those few cases where they address the materials and services which can support more sustainable practices, the communication of databases is still driven by the economic dimension. For example, incandescent lamps and LEDs (Light Emitting Diode) are differentiated by cost, while they could also be differentiated by energy efficiency criteria (e.g., energy consumption, lux, durability). In the reuse of materials, as in the case of concrete forms, the information contained in the databases refers more to the cost variation of the activity as a function of material consumption (wood or metal) than to the lower environmental impact.

Some progress can be seen in the adoption of those most popular building systems such as solar capture for thermal and photovoltaic applications. The CYPE GP and BDCCM provide chapters which bring together complete solar systems (capture, storage, and distribution) while on the ORSE only a few isolated activities. At the SINAPI base, in turn, no solar pickup services were identified, 
despite being an energy source that has been encouraged through financing from the Caixa Econômica Federal itself, the SINAPI maintainer.

It is observed that the few environmental actions identified in the databases have any associated economic advantage that is easily perceived by the builders or future users. This is the case in the cited examples of the use of more efficient light bulbs and the adoption of solar heating for showers (reduction of the energy bill), reuse of the forms of wood for concrete (reduction of the cost of acquiring wood).

\subsection{Public Services (Urban Infrastructure)}

The resources and services provided by the urban infrastructure (facilities) participate in the cost bases in a different way from those productive resources acquired in the construction suppliers (inputs and services). Inputs of origin in the construction market generally have their costs identified and quantified in each of the unitary compositions of which they are part. On the other hand, items such as water and energy are neglected despite these being present in most constructive activities and with significant environmental impacts [21].

In most of the bases, the consumption of water and energy are not quantified per service and are often considered as simple expenses linked to administrative activities. The lack of quantification of water and energy consumption makes it difficult not only to estimate the demand for these resources, but also makes it unfeasible to use control tools such as the $\mathrm{ABC}$ curve to analyze the total consumption [82,83], or the S curve to study their consumption over time [84].

An analysis of the compositions of the cited databases found that many of their processes demand water for various uses: as input to be added (e.g., production of concrete and mortar, dilution and paints); as facilitator (e.g., sprinklers control the humidity of aggregates and reduce dust emissions); and potable water for worker.

The results were classified and grouped by use and activities. The first group brought together the water use in traditional construction activities (e.g., foundation, structure, fences, and finishes), where it is usually incorporated into the constructive piece. The second group brought together those activities of higher water demand, such as earth moving, deep foundations and surface cleaning. The third group was the use of water by the construction site (e.g., to maintain its facilities and reducing dust) and drinking water consumption by workers.

In the first group (traditional constructive activities), only GP CYPE and BDCCM consider water consumption as a variable cost, which would allow analyzing both water demand per service and comparing it between different services. In the other bases analyzed (TCPO, SINAPI, and ORSE) water consumption is considered only as a fixed expense.

In the second group (services with high water demand), only the BCCA shows water as a variable cost in the unitary composition of the activities. However, the BCCA addresses the use of potable water even for earthmoving services, when it could encourage the use of reuse water, for example. A search on the BCCA identified 67 citations related to the potable water as an input, most of them in ground compaction services (using a tanker truck), foundation piles (by drilling or drilling), surface cleaning by blasting, landscaping. In the BDCCM and GP CYPE, the cost of water was not directly identified, only in those services of movement and compaction it is indirectly predicted through the cost of the tanker truck. In TCPO and ORSE the consumption and cost of water are not evidenced in their compositions.

Among the three, the third group of water use (construction site) was the one that showed less control over the water consumption, whereas the bases did not present indicators to monitor the water demand of the construction site activities.

The approach to energy consumption was like that applied to water consumption. Despite the use of energy is associated with those electrical machines and equipment (e.g., compressors, elevators, chainsaws) contained in the cost compositions, the analyzed bases considered the consumption of electric energy as an expense instead of a variable cost of the activity. 
In the review of the environmental literature, some strategies seek to fill this lack of quantitative data to estimate water and energy consumption. Gangolells et al. [21] combined statistical data about water and energy consumption by area constructed with the quantities of construction services. Souza [46] estimated the water demand from standard quantities, services specifications, technical recommendations, and the worker numbers.

\subsection{Machinery, Transport Services and Pollution}

TCPO adopted the term "machines" for heavy equipment (e.g., excavators, cargo lifts, cranes, pile drivers) and the term "tool" for small equipment owned by the operator.

It was observed that in heavy-duty activities it is common for the composition to carry the name of the main machine. While, in those activities which involve vehicles to support their execution, the composition is named according to the function performed by these vehicles (transportation, loading, and unloading). In the databases, in general, the larger machines and vehicles and their compositions are grouped into specific chapters, such as the chapter "Machines, Vehicles and Equipment" in TCPO, "Infrastructure" in the ORSE, in the class "Cost machinery and equipment" at SINAPI, and "Machinery" at BCCA and BDCCM.

The circulation of machines and equipment contributes for generating several impacts and nuisances in the direct environment (neighborhood) and in the urban space. Among these externalities, it is the emission of smoke, noise, and vibration. However, the databases analyzed do not show environmental indicators that could be used to control these impacts.

Diesel oil consumption data by activity were identified in 129 TCPO compositions, wherein they consider the productive time of the machines and equipment. However, in these compositions, no references to associated terms such as "smoke" or "pollution" have been identified in their enforcement procedures. In the other bases (SINAPI, ORSE, CYPE, BCCA, and BDCCM), no fuel consumption data were found.

In the search, the term vibration was ordinarily associated with the description of those machines involved (e.g., self-propelled roller, vibratory plate compactor, immersion vibrator) or for achieving some requirements in the concrete pieces (e.g., density, consistency). In the databases, no vibration control procedures were identified, even for those pile driving and demolition activities. Exceptions were the activities involving the use of explosives and risks to the site and surrounding areas, which require planning the sequence of the service to reduce risks [24].

An alternative to estimating these aspects would be to use a combination of intensity and time factors. For example, fuel consumption would serve as a basis for estimating air pollution (burning of gases and smoke), noise generation rate to estimate noise pollution and the operating time of some machines to estimate nuisance from vibration.

\subsection{Safety and Health (Occupational)}

The analyzed cost databases present the same standard for labor classification and quantification. Demand for labor is classified according to the professional activity (e.g., masons, carpenters, electricians) which is assigned a unit cost per hour (man-hour).

The direct cost of labor is the sum of each professional's time multiplied by their estimated time for that activity, also considering the productivity patterns inherent to the activity and the team and technologies involved [24]. Thus, knowing the amount of each activity may be extracted the workers' times in a global way or by professional activity allowing to estimate the labor costs and to estimate the teams. In general, work safety programs use the size of these staffs and the risks normally associated with these professional activities to plan the demand for protective equipment (individual and collective), as well as for planning the training, supervision and control actions.

Considering that they adopt the professional profile as a key criterion for classifying the labor demand, the structure of these databases may lead users to ignore important factors such as working conditions and risk exposure. In their descriptions, the TCPO, ORSE and GP CYPE databases address 
the executive regulations and procedure of each activity applicable to environmental health and safety issues In the bases analyzed, the main safety standard is the NR-18 Working Conditions and Environment in the Construction Industry [85]. The description of the activities mentions several of the physical, chemical and biological hazards associated with the construction that are listed by NR-18 (e.g., electric shock, collapse, particle projection, explosion, falling objects, falling height).

However, quantitative data that would allow measuring these risks were not found, therefore, restricting the choice of safety measures according to subjective criteria. This approach does not distinguish those cases where the same activity performed under different conditions may present different risks. For example, the same exterior facade coating activity has different risks when performed on the ground floor compared to that performed on higher floors. In this sense, cost bases could, in addition to informing the risk according to the activity worker profile, also inform the risks according to the working conditions and exposure to the risk (e.g., fall in height, fall of objects).

\subsection{Overall Results}

Table 7 presents the normalized performance values by theme according to Equation (2) and the global values for each analyzed cost base obtained with Equation (3).

Table 7. Overall value $(\mathrm{G})$ of the performance of the cost databases.

\begin{tabular}{cccccccc}
\hline Theme & TCPO & SINAPI & ORSE & CYPE & BCCA & BDCCM & Average \\
\hline IC & 0.7 & 0.2 & 0.8 & 1.0 & 0.2 & 0.5 & 0.6 \\
RC/WG & 0.4 & 0.1 & 0.4 & 0.8 & 0.4 & 0.5 & 0.4 \\
WC/EC & 0.0 & 0.0 & 0.0 & 0.2 & 0.3 & 0.2 & 0.1 \\
MC/PE & 0.5 & 0.5 & 0.4 & 0.4 & 0.4 & 0.4 & 0.4 \\
H/S & 0.7 & 0.2 & 0.7 & 0.7 & 0.2 & 0.2 & 0.5 \\
Sum (G) & 2.3 & 1.0 & 2.3 & 3.1 & 1.5 & 1.8 & \\
\hline
\end{tabular}

Notes: Information and Communication (I/C), Resources consumption and Waste generation (RC/WG), Water and Energy Consumption (WC/EC), Machinery Circulation and Pollution Emissions (MC/PE), Healthy and Safety Occupational (H/S).

In general, cost databases were low performing in most aspects of environmental communication, especially data on water and energy consumption, use of machines and emission of pollution emission, and information related to occupational health and safety. The group consumption of water and energy was the one that presented the worst result according to the averages of performance of the selected cost bases. In fact, except for BCCA, the other bases consider water and energy consumption as an expense without presenting a method to quantify it as a function of the volume of activities.

Figure 5 shows the performance of each cost basis for the global values according to the defined evaluation aspects.

Considering the six bases, the CYPE Price Generator (GP CYPE) was the one that presented a better score, registering 3.1 points, followed by the Table of Compositions of Prices for Budgets (TCPO) of the Editora Pini and the System of Budget of Works of Sergipe (ORSE), both with 2.3 points.

In the group with the intermediate results were the regional bases of Spain, the Base of Prices of the Construction of the Community of Madrid (BDCCM) with 1.8 points and the Base of Costs of the Construction of Andalusia (BCCA), with 1.5 points. The worst performance was the National System for Costing and Indices of Civil Construction (SINAPI), with an overall performance of only 1 point. 


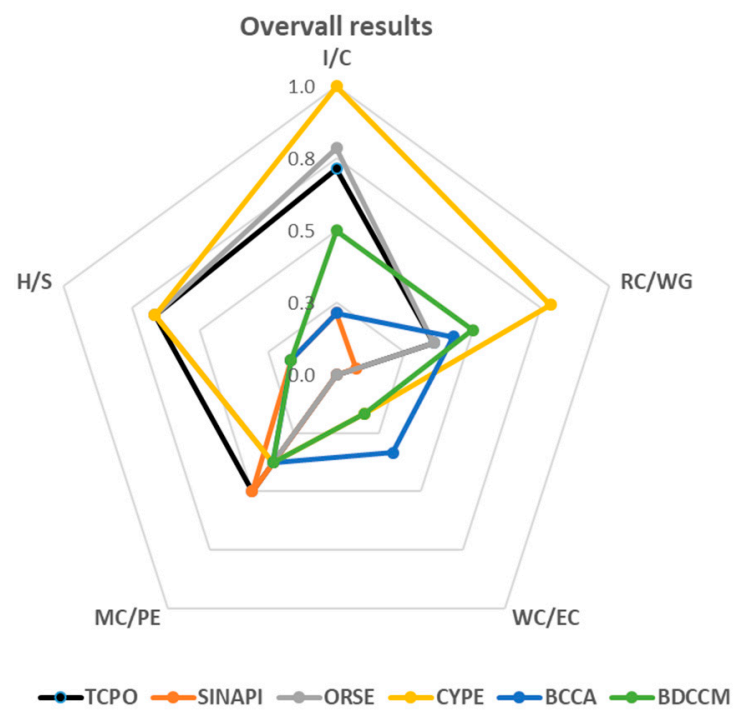

Figure 5. Radar diagrams for Environmental Communication Assessment. Notes: Information and Communication (I/C), Resources consumption and Waste generation (RC/WG), Water and Energy Consumption (WC/EC), Machinery Circulation and Pollution Emissions (MC/PE), Healthy and Safety Occupational $(\mathrm{H} / \mathrm{S})$.

\section{Conclusions}

This article performed an analysis of a set of cost bases for identifying relationships between cost data and environmental information. Firstly, it carried out a systematic review of the international literature on cost bases in environmental studies, followed by documentary analysis of the programs of the engineering courses to survey the most cited cost bases. This first step characterized the state of the art and state of the technique for definition of the collection and data analysis model. Then, an environmental communication assessment matrix was applied to the selected cost databases. Finally, the performance results of each cost base were compared.

The use of cost bases in environmental studies has been increasing in recent decades. However, as observed in the literature review applied, it was verified that such bases are adopted as an auxiliary tool to fill the lack of quantitative data in some instruments of environmental assessment. Thus, from the structure and data of these cost databases are extracted information which combined with environmental analysis tools allow for obtaining environmental indicators such as consumption of resources (materials, water, and energy), generation of waste and pollution emission. This process could be better systematized if the cost bases incorporated direct environmental indicators instead of requiring correlations with other instruments. This action would also improve the dissemination of environmental information among its users.

A documentary analysis has identified that such cost databases are one relevant content in the education of Brazilian civil engineering according to the pedagogical projects of their courses. However, it was observed a concentration in few bases and a low integration with environmental themes. Although the analysis was applied to a wide range of courses (one for each of the 27 units of the Brazilian federation) to cover possible regional differences, the results show that the citations are restricted to only three bases, all of them of national scope: the Price Composition Table (TCPO), the National System of Costs Survey and Indices of Civil Construction (SINAPI), and the System of Reference Costs of Works (SICRO). Among the three bases cited by the 27 Brazilian courses selected, TCPO obtained the highest number of citations, with 21 occurrences $(78 \%)$, well above SINAPI, with 4 cases, and SICRO, with only 3 cases.

In contrast, while in the analysis of the programs of the courses in Brazil the bases mentioned were national in scope, in the review of the literature, the regional bases in Spain prevailed, such as the 
Base of Costs of the Construction of Andalusia (BCCA) and the Base of Prices of the Construction of the Community of Madrid (BCCM).

Other findings come from the asymmetry of the correlation of databases with topics such as construction management and environmental management. The cost databases have a high affinity with themes such as physical-financial planning of the work, $85 \%$ of the cases. However, the same databases present an association of only $7 \%$ to environmental issues, such as waste management ( 1 case) and life-cycle assessment ( 1 case). These results point to the need to revise the course programs as a strategy to improve the insertion of the environmental dimension in the education of engineers and in their professional practice.

Finally, the application of the evaluation matrix of the environmental communication allowed mapping the performance of the cost bases according to the selected themes and the comparison among those. It was observed that, although the analyzed cost bases have similar structures for the classification of the records, they are very different as regards the quality of the environmental information according to the evaluation criteria applied by research.

The CYPE Price Generator, international coverage, presented the best results followed by TCPO, national coverage, both cost bases are maintained by private institutions. The ORSE registered the third best performance, which is maintained by the public sector and of regional coverage (State of Sergipe in Brazil). The second group had the worst performers. The regional bases of Spain, Base of Costs of the Construction of Andalusia (BCCA) and Base of Prices of the Construction of the Community of Madrid (BDCCM), had intermediate performance. The National System for Research in Costs and Indices of Civil Construction (SINAPI), maintained by public agent, registered the worst performance among the six cost bases analyzed.

It is important to note that the bases of the regions of Spain of Andalusia and Madrid are part of initiatives of local governments to promote the improvement of the performance of the regional construction sector. Such a strategy could be extended to improve tools in other local contexts. SINAPI in Brazil has a great potential for disseminating environmental information in the national construction sector as it is a mandatory reference in constructions financed with federal government resources and has a wide data collection structure, maintained by the Caixa Econômica Federal (CEF) and by the Brazilian Institute of Geography and Statistics (IBGE).

According to the results, the use of computerized systems can contribute to improved access to data, the search for indicators and the generation of more complete reports aimed at improving the quality of information and guiding building practices. In this sense also, the sector in Brazil needs a consolidated model for the classification of construction data in order to facilitate the collection and communication of data to users and other management systems. The agents involved in the development of these tools have an important role in this action, considering that these systems reach a large public of users of the construction sector, comprising students in training (graduates and technicians), budgeting, planning engineers and managers.

The results point to the confirmation of the initial hypothesis, in which traditional tools such as cost bases can contribute beyond the economic management of the construction process. These cost bases, incorporating new indicators, can help to plan and control local impacts and increase the environmental awareness of construction agents aiming at lower impact sites.

Author Contributions: L.C.A.B., S.F.C., and A.K. conceived the study and designed the conceptual research framework. L.C.A.B. performed the data collection and analysis. S.F.C., R.D.A.C., and A.K. reviewed the analysis. L.C.A.B. wrote the paper. S.F.C., R.D.A.C., and A.K. reviewed the final version of the manuscript.

Funding: This research received no external funding.

Acknowledgments: The authors acknowledgments the important collaboration of Clean Technology Network (TECLIM) of the Department of Environmental Engineering at Federal University of Bahia (UFBA), and the Federal Institute of Bahia (IFBA). The authors are also grateful for the contributions of Juan Pedro Moreno Delgado of the Federal University of Bahia and João Luiz Calmon Nogueira da Gama of the Federal University of Espirito Santo.

Conflicts of Interest: The authors declare no conflict of interest. 


\section{Abbreviations}

BCCA Base de Costes de la Construcción de Andalucía (in Spanish)

BDCCM Base de Datos de la Construcción de la Comunidad de Madrid (in Spanish)

GP CYPE Generador de precios da Cype Ingenieros (in Spanish)

LNEC Laboratório Nacional de Engenharia Civil (in Portuguese)

ORSE Sistema de Orçamento de Obras de Sergipe

SICRO Sistema de Custos Referenciais de Obras

SINAPI Sistema Nacional de Pesquisa de Custos e Índices da Construção Civil

TCPO Tabela de Composições de Preços para Orçamentos

\section{Appendix A}

Table A1. Websites consulted to obtain Civil Engineering Course Projects and their programs by Brazilian regions, federation units and Education Institutions (Authors, 2018).

\begin{tabular}{|c|c|c|c|c|}
\hline Region & UF & Institution & Acronym & Website \\
\hline \multirow{7}{*}{$\begin{array}{l}\text { 胥 } \\
\text { Z }\end{array}$} & $\mathrm{AC}$ & $\begin{array}{l}\text { Federal University of } \\
\text { Acre }\end{array}$ & UFAC & $\begin{array}{l}\text { https:/ / portal.ufac.br/ementario/ } \\
\text { curriculo.action?v=335 }\end{array}$ \\
\hline & $\mathrm{AP}$ & $\begin{array}{l}\text { Federal University of } \\
\text { Amapa }\end{array}$ & UNIFAP & $\begin{array}{l}\text { http://biblioteca.ufam.edu.br/ } \\
\text { attachments/article/259/Projeto\% } \\
\text { 20Pedag\%C3\%B3gico\%20curso } \% \\
\text { 20Engenharia\%20Civil.compressed. } \\
\text { pdf }\end{array}$ \\
\hline & $\mathrm{AM}$ & $\begin{array}{l}\text { Federal University of } \\
\text { Amazonas }\end{array}$ & UFAM & $\begin{array}{l}\text { http://www2.unifap.br/engcivil/ } \\
\text { files/2014/01/PPC-Civil-Final-16_ } \\
\text { 10_12.pdf }\end{array}$ \\
\hline & PA & $\begin{array}{l}\text { Federal University of } \\
\text { Pará }\end{array}$ & UFPA & $\begin{array}{l}\text { http://www.camtuc.ufpa.br/index. } \\
\text { php/engenharia-civil }\end{array}$ \\
\hline & $\mathrm{RO}$ & $\begin{array}{l}\text { Federal Institute of } \\
\text { Rondônia }\end{array}$ & IFRO & $\begin{array}{l}\text { http://portal.ifro.edu.br/calama/ } \\
\text { cursos/4719-engenharia-civil }\end{array}$ \\
\hline & $\mathrm{RR}$ & $\begin{array}{l}\text { Federal University of } \\
\text { Roraima }\end{array}$ & UFRR & $\begin{array}{l}\text { http://ufrr.br/engcivil/index.php? } \\
\text { option=com_phocadownload\& } \\
\text { view=category\&id=11: } \\
\text { disciplinas\&Itemid=312 }\end{array}$ \\
\hline & $\mathrm{TO}$ & $\begin{array}{l}\text { Federal University of } \\
\text { Tocantins }\end{array}$ & UFT & $\begin{array}{l}\text { http://www.uft.edu.br/ } \\
\text { centroengenharias/ementas/ }\end{array}$ \\
\hline \multirow{7}{*}{ 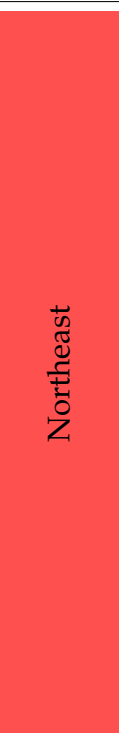 } & $\mathrm{AL}$ & $\begin{array}{l}\text { Federal University of } \\
\text { Alagoas }\end{array}$ & UFAL & \multirow{7}{*}{$\begin{array}{l}\text { https://ufal.br/estudante/ } \\
\text { graduacao/projetos-pedagogicos/ } \\
\text { campus-maceio/ppc-eng-civil.pdf } \\
\text { http://www2.eng.ufba.br/site/ } \\
\text { index.php/civil/ementas } \\
\text { http: } \\
\text { //www.deecc.ufc.br/Download/ } \\
\text { http://www.ccec.ufma.br/index. } \\
\text { php/projeto- } \\
\text { https://estudante.ifpb.edu.br/ } \\
\text { media/cursos/25/documentos/ } \\
\text { PPC_Engenharia_Civil-CZ.pdf } \\
\text { https: } \\
\text { //portal.ifpe.edu.br/campus/recife/ } \\
\text { cursos/superiores/bacharelados/ } \\
\text { engenharia-civil/projeto-pedagogico } \\
\text { http: } \\
\text { //www.leg.ufpi.br/subsiteFiles/cc/ } \\
\text { arquivos/files/eng_civil_cmpp.pdf }\end{array}$} \\
\hline & BA & $\begin{array}{l}\text { Federal University of } \\
\text { Bahia }\end{array}$ & UFBA & \\
\hline & $\mathrm{CE}$ & $\begin{array}{l}\text { Federal University of } \\
\text { Ceara }\end{array}$ & UFC & \\
\hline & MA & $\begin{array}{l}\text { Federal University of } \\
\text { Maranhão }\end{array}$ & UFMA & \\
\hline & PB & $\begin{array}{l}\text { Federal Institute of } \\
\text { Paraíba }\end{array}$ & IFPB & \\
\hline & PE & $\begin{array}{l}\text { Federal Institute of } \\
\text { Pernambuco }\end{array}$ & IFPE & \\
\hline & PI & $\begin{array}{l}\text { Federal University of } \\
\text { Piauí }\end{array}$ & UFPI & \\
\hline
\end{tabular}


Table A1. Cont.

\begin{tabular}{|c|c|c|c|c|}
\hline \multirow{6}{*}{ 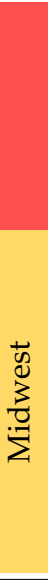 } & $\mathrm{RN}$ & $\begin{array}{l}\text { Federal University of Rio } \\
\text { Grande do Norte }\end{array}$ & UFRN & \multirow{6}{*}{$\begin{array}{l}\text { https:/ / sigaa.ufrn.br/sigaa/public/ } \\
\text { curso/ppp.jsf?lc=pt_BR\&id=2000025 } \\
\text { http:/ / www.ifs.edu.br/cursos- } \\
\text { superiores/259-cursos/superiores/ } \\
\text { 4306-bacharelado-em-engenharia- } \\
\text { civil\#ppc } \\
\text { https://matriculaweb.unb.br/ } \\
\text { graduacao/oferta_dis.aspx?cod=162 } \\
\text { http:/ / www.eec.ufg.br/up/140/o/ } \\
\text { Eng_Civil_Anexo_II_Ementas_e_- } \\
\text { Bibliografica_Grade_2009-1.pdf } \\
\text { https://www.ufmt.br/ufmt/site/ } \\
\text { ensino/consultaPlanoEnsino/Cuiaba } \\
\text { http://engenhariacivil.sites.ufms.br/ } \\
\text { curso-2/projeto-pedagogico/ }\end{array}$} \\
\hline & SE & $\begin{array}{l}\text { Federal University of } \\
\text { Sergipe }\end{array}$ & UFS & \\
\hline & DF & University of Brasília & UNB & \\
\hline & $\mathrm{GO}$ & $\begin{array}{l}\text { Federal University of } \\
\text { Goiás }\end{array}$ & UFG & \\
\hline & MT & $\begin{array}{l}\text { Federal University of } \\
\text { Mato Grosso }\end{array}$ & UFMT & \\
\hline & MS & $\begin{array}{l}\text { Federal University of } \\
\text { Mato Grosso do Sul }\end{array}$ & UFMS & \\
\hline \multirow{4}{*}{ 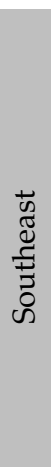 } & ES & $\begin{array}{l}\text { Federal University of } \\
\text { Espírito Santo }\end{array}$ & UFES & $\begin{array}{l}\text { http:/ / www.engenhariacivil.ufes.br/ } \\
\text { projeto-pedag\%C3\%B3gico-e- } \\
\text { estrutura-curricular }\end{array}$ \\
\hline & MG & $\begin{array}{l}\text { Federal University of } \\
\text { Minas Gerais }\end{array}$ & UFMG & \multirow{3}{*}{$\begin{array}{l}\text { https:/ / www.eng.ufmg.br/portal/ } \\
\text { https:/ / www.siga.ufrj.br/sira/ } \\
\text { temas/zire/frameConsultas.jsp? } \\
\text { mainPage=/repositorio-curriculo/ } \\
\text { F011BEAD-92A4-F79A-2A99- } \\
\text { E698E5E08ACF.html } \\
\text { https: } \\
\text { //uspdigital.usp.br/jupiterweb/ }\end{array}$} \\
\hline & $\mathrm{RJ}$ & $\begin{array}{l}\text { Federal University of Rio } \\
\text { de Janeiro }\end{array}$ & UFRJ & \\
\hline & SP & University of São Paulo & USP & \\
\hline \multirow{3}{*}{ 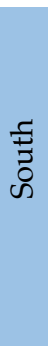 } & PR & $\begin{array}{l}\text { Federal University of } \\
\text { Technology-Parana/Brazil }\end{array}$ & UTFPR & \multirow{3}{*}{$\begin{array}{l}\text { http://www.utfpr.edu.br/curitiba/ } \\
\text { cursos/bacharelados/Ofertados- } \\
\text { neste-Campus/engenharia-de- } \\
\text { producao-civil/planos-de-ensino } \\
\text { http://www.unipampa.edu.br/ } \\
\text { portal/documentos } \\
\text { http: } \\
\text { //ecv.paginas.ufsc.br/files/2014/06/ } \\
\text { Projeto_Pedagógico_2014.pdf }\end{array}$} \\
\hline & RS & $\begin{array}{l}\text { Federal University of } \\
\text { Pampa }\end{array}$ & UNIPAMPA & \\
\hline & SC & $\begin{array}{l}\text { Federal University of } \\
\text { Santa Catarina }\end{array}$ & UFSC & \\
\hline
\end{tabular}

\section{Appendix B}

Table A2. Disciplines of selected civil engineering courses related to cost databases by Brazilian regions, states and Education Institutions (Authors, 2018).

\begin{tabular}{|c|c|c|c|c|c|}
\hline Region & UF & Institution & Acronym & $\begin{array}{c}\text { Curricular Components that Cite Cost } \\
\text { Databases }\end{array}$ & Database \\
\hline \multirow{4}{*}{ 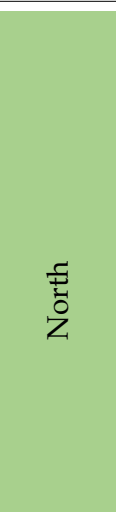 } & $\mathrm{AC}$ & $\begin{array}{l}\text { Federal } \\
\text { University of } \\
\text { Acre }\end{array}$ & UFAC & $\begin{array}{l}\text { Construction Management/ } \\
\text { Administration/Construction } \\
\text { Budget/Construction } \\
\text { Planning/Control }\end{array}$ & \\
\hline & $\mathrm{AP}$ & $\begin{array}{l}\text { Federal } \\
\text { University of } \\
\text { Amapa }\end{array}$ & UNIFAP & $\begin{array}{l}\text { Construction Budget/Construction } \\
\text { Planning and } \\
\text { Management/Construction Technology } \\
\text { I and II }\end{array}$ & TCPO \\
\hline & $\mathrm{AM}$ & $\begin{array}{l}\text { Federal } \\
\text { University of } \\
\text { Amazonas }\end{array}$ & UFAM & $\begin{array}{l}\text { Civil Construction II/Road } \\
\text { Construction and Land Works }\end{array}$ & TCPO, SICRO. \\
\hline & PA & $\begin{array}{l}\text { Federal } \\
\text { University of } \\
\text { Pará }\end{array}$ & UFPA & $\begin{array}{l}\text { Construction Budget/Construction } \\
\text { Planning and Management II/Coatings } \\
\text { Technology }\end{array}$ & $\begin{array}{l}\text { TCPO, SICRO, } \\
\text { SINAPI }\end{array}$ \\
\hline
\end{tabular}


Table A2. Cont.

\begin{tabular}{|c|c|c|c|c|c|}
\hline & $\mathrm{RO}$ & $\begin{array}{l}\text { Federal Institute of } \\
\text { Rondônia }\end{array}$ & IFRO & Construction Budget & TCPO \\
\hline & $\mathrm{RR}$ & $\begin{array}{l}\text { Federal University } \\
\text { of Roraima }\end{array}$ & UFRR & $\begin{array}{l}\text { Civil Construction/Construction } \\
\text { planning and control }\end{array}$ & ТСРО \\
\hline & $\mathrm{TO}$ & $\begin{array}{l}\text { Federal University } \\
\text { of Tocantins }\end{array}$ & UFT & $\begin{array}{l}\text { Building Construction Technology } \\
\text { II/Construction planning and control }\end{array}$ & - \\
\hline \multirow{9}{*}{ 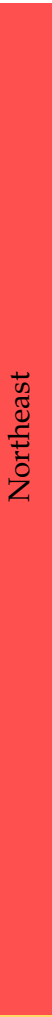 } & $\mathrm{AL}$ & $\begin{array}{l}\text { Federal University } \\
\text { of Alagoas }\end{array}$ & UFAL & $\begin{array}{l}\text { Management of construction } \\
\text { projects/Planning and management of } \\
\text { production in } \\
\text { construction/Construction Technology } \\
\text { I and II }\end{array}$ & - \\
\hline & $\mathrm{BA}$ & $\begin{array}{l}\text { Federal University } \\
\text { of Bahia }\end{array}$ & UFBA & $\begin{array}{l}\text { Civil Construction I and } \\
\text { II/Administration applied to Civil } \\
\text { Engineering }\end{array}$ & ТCPO \\
\hline & $\mathrm{CE}$ & $\begin{array}{l}\text { Federal University } \\
\text { of Ceara }\end{array}$ & UFC & $\begin{array}{l}\text { Building Construction I/Cost } \\
\text { Planning/Construction Management }\end{array}$ & TCPO \\
\hline & MA & $\begin{array}{l}\text { Federal University } \\
\text { of Maranhão }\end{array}$ & UFMA & $\begin{array}{l}\text { Budget/Construction Planning and } \\
\text { Control/Civil Construction I and II }\end{array}$ & ТСРО \\
\hline & $\mathrm{PB}$ & $\begin{array}{l}\text { Federal Institute of } \\
\text { Paraíba }\end{array}$ & IFPB & $\begin{array}{l}\text { Life cycle costing/Construction } \\
\text { planning and budgeting }\end{array}$ & TCPO \\
\hline & PE & $\begin{array}{l}\text { Federal Institute of } \\
\text { Pernambuco }\end{array}$ & IFPE & $\begin{array}{l}\text { Specifications and } \\
\text { budget/Construction } \\
\text { management/Production planning and } \\
\text { control }\end{array}$ & TCPO \\
\hline & PI & $\begin{array}{l}\text { Federal University } \\
\text { of Piauí }\end{array}$ & UFPI & $\begin{array}{l}\text { Administration applied to } \\
\text { Engineering/Building } \\
\text { Construction/Construction Planning } \\
\text { and Control/Construction Equipment }\end{array}$ & TCPO, SICRO \\
\hline & $\mathrm{RN}$ & $\begin{array}{l}\text { Federal University } \\
\text { of Rio Grande do } \\
\text { Norte }\end{array}$ & UFRN & $\begin{array}{l}\text { Civil Construction 2/Construction } \\
\text { Management }\end{array}$ & TCPO \\
\hline & SE & $\begin{array}{l}\text { Federal University } \\
\text { of Sergipe }\end{array}$ & UFS & $\begin{array}{l}\text { Planning and Management in } \\
\text { Production of Buildings/Construction } \\
\text { Budget }\end{array}$ & TCPO \\
\hline \multirow{4}{*}{$\sum_{\substack{\infty \\
\infty}}^{+}$} & $\mathrm{DF}$ & $\begin{array}{l}\text { University of } \\
\text { Brasília }\end{array}$ & UNB & $\begin{array}{l}\text { Construction Technology } \\
\text { I/Construction Planning and } \\
\text { Control/Road Design }\end{array}$ & TCPO, SICRO \\
\hline & GO & $\begin{array}{l}\text { Federal University } \\
\text { of Goiás }\end{array}$ & UFG & $\begin{array}{l}\text { Civil Construction } 1 \text { and } \\
2 / \text { Construction Planning and Control }\end{array}$ & TCPO \\
\hline & MT & Federal University & UFMT & Planning Techniques in Civil & - \\
\hline & MS & $\begin{array}{l}\text { Federal University } \\
\text { of Mato Grosso do } \\
\text { Sul }\end{array}$ & UFMS & $\begin{array}{l}\text { Civil Construction/Civil Construction } \\
\text { Management/ Construction } \\
\text { Planning/Quality in Civil Construction }\end{array}$ & TCPO \\
\hline \multirow{4}{*}{ 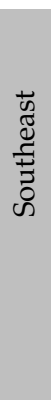 } & ES & $\begin{array}{l}\text { Federal University } \\
\text { of Espírito Santo }\end{array}$ & UFES & $\begin{array}{l}\text { Management of Civil } \\
\text { Construction/Project Management, }\end{array}$ & \\
\hline & MG & $\begin{array}{l}\text { Federal University } \\
\text { of Minas Gerais }\end{array}$ & UFMG & $\begin{array}{l}\text { Civil Construction } \\
\text { Management/Construction Technology } \\
1 \text { and } 2\end{array}$ & TCPO \\
\hline & RJ & $\begin{array}{l}\text { Federal University } \\
\text { of Rio de Janeiro }\end{array}$ & UFRJ & $\begin{array}{l}\text { Buildings/Construction } \\
\text { Management/Project } \\
\text { Management/Construction Planning. }\end{array}$ & TCPO \\
\hline & $\mathrm{SP}$ & $\begin{array}{l}\text { University of São } \\
\text { Paulo }\end{array}$ & USP & $\begin{array}{l}\text { Management of Construction } \\
\text { Production/Planning and Construction } \\
\text { Costs/Civil Construction I and II }\end{array}$ & \\
\hline
\end{tabular}


Table A2. Cont.

\begin{tabular}{|c|c|c|c|c|c|}
\hline \multirow{3}{*}{ 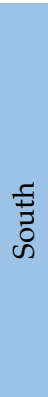 } & PR & $\begin{array}{l}\text { Federal } \\
\text { University of } \\
\text { Technology } \\
\text {-Parana }\end{array}$ & UTFPR & $\begin{array}{l}\text { Specifications and budgets/Project } \\
\text { management. Construction } \\
\text { management/Heavy construction } \\
\text { work. }\end{array}$ & TCPO. SINAPI \\
\hline & RS & $\begin{array}{l}\text { Federal } \\
\text { University of } \\
\text { Pampa }\end{array}$ & UNIPAMPA & $\begin{array}{l}\text { Budget and construction } \\
\text { scheduling/Construction } \\
\text { Management/Design of road } \\
\text { structures. }\end{array}$ & ТСРО \\
\hline & SC & $\begin{array}{l}\text { Federal } \\
\text { University of } \\
\text { Santa Catarina }\end{array}$ & UFSC & $\begin{array}{l}\text { Construction Management/Civil } \\
\text { Construction Techniques II }\end{array}$ & TCPO, SICRO \\
\hline
\end{tabular}

\section{References}

1. Webb, R.; Bai, X.; Smith, M.S.; Costanza, R.; Griggs, D.; Moglia, M.; Neuman, M.; Newman, P.; Newton, P.; Norman, B.; et al. Sustainable urban systems: Co-design and framing for transformation. Ambio 2017, 1-21. [CrossRef] [PubMed]

2. Joint Research Center, JCR. Best Environmental Management Practice for the Building and Construction Sector; EcoManagement and Audit Scheme (EMAS): Seville, Spain, 2012.

3. Ferreira, J.; Pinheiro, M.D.; de Brito, J. Portuguese sustainable construction assessment tools benchmarked with BREEAM and LEED: An energy analysis. Energy Build. 2014, 69, 451-463. [CrossRef]

4. Haapio, A.; Viitaniemi, P. A critical review of building environmental assessment tools. Environ. Impact Assess. Rev. 2008, 28, 469-482. [CrossRef]

5. Silva, V.G. Metodologias de avaliação de Desempenho Ambiental de Edifícios: Estado Atual e Discussão Metodológica; Finep-Financiadora de Estudos e Projetos, Ministério da Ciência e Tecnologia e Inovação: São Paulo, Brazil, 2007; p. 60.

6. Kneifel, J. Life-cycle carbon and cost analysis of energy efficiency measures in new commercial buildings. Energy Build. 2010, 42, 333-340. [CrossRef]

7. De Magalhães, R.F.; Danilevicz, Â.d.M.F.; Saurin, T.A. Reducing construction waste: A study of urban infrastructure projects. Waste Manag. 2017. [CrossRef] [PubMed]

8. Wong, P.S.P.; Lindsay, A.; Crameri, L.; Holdsworth, S. Can energy efficiency rating and carbon accounting foster greener building design decision? An empirical study. Build. Environ. 2015, 87, 255-264. [CrossRef]

9. Wong, I.L.; Kruger, E. Comparing energy efficiency labelling systems in the EU and Brazil: Implications, challenges, barriers and opportunities. Energy Policy 2017, 109, 310-323. [CrossRef]

10. Bocchini, P.; Frangopol, D.M.; Ummenhofer, T.; Zinke, T. Resilience and Sustainability of Civil Infrastructure: Toward a Unified Approach. J. Infrastruct. Syst. 2014, 20, 04014004. [CrossRef]

11. Tadeu, S.; Rodrigues, C.; Tadeu, A.; Freire, F.; Simões, N. Energy retrofit of historic buildings: Environmental assessment of cost-optimal solutions. J. Build. Eng. 2015, 4, 167-176. [CrossRef]

12. Santos, R.; Costa, A.A.; Grilo, A. Bibliometric analysis and review of Building Information Modelling literature published between 2005 and 2015. Autom. Constr. 2017, 80, 118-136. [CrossRef]

13. Tsimplokoukou, K.; Lamperti, M.; Negro, P. Building Design for Safety and Sustainability; Joint Research Centre, Institute for the Protection and Security of the Citizen: Ispra, Italy, 2014.

14. Chong, H.-Y.; Lee, C.-Y.; Wang, X. A mixed review of the adoption of Building Information Modelling (BIM) for sustainability. J. Clean. Prod. 2017, 142, 4114-4126. [CrossRef]

15. Almeida, M.; Mateus, R.; Ferreira, M.; Rodrigues, A. Life-cycle costs and impacts on energy-related building renovation assessments. Int. J. Sustain. Build. Technol. Urban Dev. 2016, 7, 206-213. [CrossRef]

16. De Carvalho, A.; Granja, A.; da Silva, V. A Systematic Literature Review on Integrative Lean and Sustainability Synergies over a Building's Lifecycle. Sustainability 2017, 9, 1156. [CrossRef]

17. Lowe, D.J.; Emsley, M.W.; Harding, A. Predicting Construction Cost Using Multiple Regression Techniques. J. Constr. Eng. Manag. 2006, 132, 750-758. [CrossRef]

18. Zhang, D.; Gao, Z. Project time and cost control using building information modeling. In Proceedings of the International Conference on Construction and Real Estate Management 2013, Karlsruhe, Germany, 10-11 October 2013; pp. 545-554. [CrossRef] 
19. Kim, G.-H.; Park, H.-Y.; Shin, J. An assessment of the accuracy of cost estimation using building information modeling in design process. Appl. Mech. Mater. 2013, 291-294, 2822-2825. [CrossRef]

20. Chen, Z.; Li, H. Environmental Management in Construction: A Quantitative Approach; Taylor \& Francis Group: Abingdon, UK, 2006; ISBN 0203030362.

21. Gangolells, M.; Casals, M.; Gassó, S.; Forcada, N.; Roca, X.; Fuertes, A. A methodology for predicting the severity of environmental impacts related to the construction process of residential buildings. Build. Environ. 2009, 44, 558-571. [CrossRef]

22. Cype Ingenieros Generator Prices for Construction Version Brasil. Available online: http://www.brasil. geradordeprecos.info/ (accessed on 1 December 2017). (In Portuguese)

23. Andalusian Government. BCCA Base de Costes de la Construcción de Andalucia 2017; Consejería de Fomento y Vivienda de la Junta de Andalucía: Andalúcia, Spain, 2017.

24. PINI. Tables for Compositions of Prices for Budgets (TCPO); PINI: Rio de Janeiro, Brazil, 2013. (In Portuguese)

25. Li, X.; Yang, F.; Zhu, Y.; Gao, Y. An assessment framework for analyzing the embodied carbon impacts of residential buildings in China. Energy Build. 2014, 85, 400-409. [CrossRef]

26. Sandanayake, M.; Zhang, G.; Setunge, S. Environmental emissions at foundation construction stage of buildings-Two case studies. Build. Environ. 2016, 95, 189-198. [CrossRef]

27. Chen, Z.; Li, H.; Wong, C.T.C. Environmental Management of Urban Construction Projects in China. J. Constr. Eng. Manag. 2000, 126, 320-324. [CrossRef]

28. Gangolells, M.; Casals, M.; Forcada, N.; Macarulla, M. Predicting on-site environmental impacts of municipal engineering works. Environ. Impact Assess. Rev. 2014, 44, 43-57. [CrossRef]

29. Kazak, J.K.; Van Hoof, J. Decision support systems for a sustainable management of the indoor and built environment. Indoor Built Environ. 2018, 27, 1303-1306. [CrossRef]

30. Bana e Costa, C.A.; Ensslin, L.; Cornêa, É.C.; Vansnick, J.-C. Decision Support Systems in action: Integrated application in a multicriteria decision aid process. Eur. J. Oper. Res. 1999, 113, 315-335. [CrossRef]

31. de Oliveira Musse, J.; Homrich, A.S.; de Mello, R.; Carvalho, M.M. Applying backcasting and system dynamics towards sustainable development: The housing planning case for low-income citizens in Brazil. J. Clean. Prod. 2018, 193, 97-114.

32. Zou, Y.; Kiviniemi, A.; Jones, S.W. A review of risk management through BIM and BIM-related technologies. Saf. Sci. 2017, 97, 88-98. [CrossRef]

33. Banias, G.; Achillas, C.; Vlachokostas, C.; Moussiopoulos, N.; Papaioannou, I. A web-based Decision Support System for the optimal management of construction and demolition waste. Waste Manag. 2011, 31, 2497-2502. [CrossRef]

34. Paz, D.H.; Lafayette, K.P. Forecasting of construction and demolition waste in Brazil. Waste Manag. Res. 2016, 34, 708-716. [CrossRef]

35. Keenan, P.B.; Jankowski, P. Spatial Decision Support Systems: Three decades on. Decis. Support Syst. 2019, 116, 64-76. [CrossRef]

36. Borja, L.; César, S.; Cunha, R.; Kiperstok, A. A Quantitative Method for Prediction of Environmental Aspects in Construction Sites of Residential Buildings. Sustainability 2018, 10, 1870. [CrossRef]

37. European Commission. User's guide EMAS, under Regulation (EC) No 1221/2009 of the European Parliament and of the Council of 25 November 2009 on the Voluntary Participation by Organisations in a Community eco-Management and Audit Scheme (EMAS); European Commission: Brussels, Belgium, 2013.

38. Mateus, R.; Bragança, L. Sustainability assessment and rating of buildings: Developing the methodology SBToolPT-H. Build. Environ. 2011, 46, 1962-1971. [CrossRef]

39. Caixa Econômica Federal. SINAPI-Sistema Nacional de Pesquisa de Custos e Índices da Construção Civil. Available online: http:/ / www.caixa.gov.br/poder-publico/apoio-poder-publico/sinapi/Paginas/default. aspx (accessed on 2 March 2018).

40. Candy-CCS Orçamentos da Construção Civil. Available online: http:/ / orcamentos.eu/ (accessed on 12 April 2018).

41. Mália, M.; de Brito, J.; Pinheiro, M.D.; Bravo, M. Construction and demolition waste indicators. Waste Manag. Res. 2013, 31, 241-255. [CrossRef]

42. Llatas, C. A model for quantifying construction waste in projects according to the European waste list. Waste Manag. 2011, 31, 1261-1276. [CrossRef] [PubMed] 
43. Solís-Guzmán, J.; Marrero, M.; Montes-Delgado, M.V.; Ramírez-de-Arellano, A. A Spanish model for quantification and management of construction waste. Waste Manag. 2009, 29, 2542-2548. [CrossRef]

44. Haddad, A.N.; Lassio, J.G.G. de Life cycle assessment of building construction materials: CASE study for a housing complex. Rev. la Constr. 2016, 15, 69-77. [CrossRef]

45. De Lassio, J.; França, J.; Espirito Santo, K.K.; Haddad, A. Case Study: LCA Methodology Applied to Materials Management in a Brazilian Residential Construction Site. J. Eng. 2016, 2016, 8513293. [CrossRef]

46. Souza, J.L. Proposta Metodológica de Cálculo para a Pegada Hídrica na Construção Civil Imobiliária; Universidade Federal do Ceará: Fortaleza, Brazil, 2014.

47. Medeiros, L.M.; Cleonice, L.; Ivan, D.; Callejas, J.A. Contribution of life cycle assessment to the quantification of the environmental impacts of construction systems. Ambient. Construído 2018, 18, 365-385. [CrossRef]

48. Gangolells, M.; Casals, M.; Forcada, N.; Fuertes, A.; Roca, X. Model for Enhancing Integrated Identification, Assessment, and Operational Control of On-Site Environmental Impacts and Health and Safety Risks in Construction Firms. J. Constr. Eng. Manag. 2013, 138-147. [CrossRef]

49. Palacios, J.R.V.; Molina, J.F.Q. Determination of the construction cost of the different classifications for a sustainable dwelling in the City of Cuenca, Ecuador. Hábitat Sustent. 2017, 7, 28-39. [CrossRef]

50. Mateus, R.F.M.d.S. Avaliação da Sustentabilidade da Construção: PROPOSTAS para o Desenvolvimento de Edifícios mais Sustentáveis; Universidade do Minho: Braga, Portugal, 2009.

51. Serrano, A.Á.R.; Álvarez, P.S. Life Cycle Assessment in Building: A Case Study on the Energy and Emissions Impact Related to the Choice of Housing Typologies and Construction Process in Spain. Sustainability 2016, 8, 287. [CrossRef]

52. Mália, M.; de Brito, J.; Bravo, M. Indicadores de resíduos de construção e demolição para construções residenciais novas. Ambient. Construído 2011, 11, 117-130. [CrossRef]

53. Bragança, L.; Mateus, R.; Koukkari, H. Building sustainability assessment. Sustainability 2010, 2, $2010-2023$. [CrossRef]

54. Ness, B.; Urbel-Piirsalu, E.; Anderberg, S.; Olsson, L. Categorising tools for sustainability assessment. Ecol. Econ. 2007, 60, 498-508. [CrossRef]

55. John, W.M.; Prado, R.T.A. SELO AZUL CAIXA - Boas Práticas para Habitação Mais Sustentável; John, V.M., Prado, R.T.A., Eds.; Caixa Economica Federal, Páginas \& Letras: São Paulo, Brazil, 2010.

56. ITeC, Institut de Tecnologia de la Construcció de Catalunya-ITeC. Banco Estructurado de Datos de Elementos Constructivos-BEDEC. Available online: https://metabase.itec.cat/vide/ca/bedec (accessed on 6 February 2018).

57. Comunidad de Madrid. Base de Precios de la Construcción de la Comunidad de Madrid—BCC 2007. Available online: http:/ / www.madrid.org/bdccm/principal.htm (accessed on 29 November 2017).

58. Manso, A.C.; Fonseca, M.S.; Espada, J.C. Informação Sobre Custos: Fichas de Rendimentos; LNEC-Laboratório Nacional de Engenharia Civil: Lisboa, Portugal, 2005; ISBN 9724917185.

59. De Habitação, C.-C.E. Obras Públicas de Sergipe. Available online: http://www.cehop.se.gov.br/ (accessed on 3 October 2017).

60. Da Almeida, M.C. SINAPI x ORSE: Análise comparativa entre o Sistema Nacional de Pesquisa de Custos e Índices da Construção Civil e o Sistema Adotado pelo Governo do Estado de Sergipe. Câmara dos Deputados do Brasil. 2009. Available online: http://bd.camara.leg.br/bd/handle/bdcamara/3974 (accessed on 12 June 2018).

61. Limmer, C.V. Planning, Budgeting and Control of Projects and Works; Livros Tecnicos e Cientificos: São Paulo, Brazil, 1997; ISBN 852161084X. (In Portuguese)

62. Yazigi, W. A Técnica de Edificar; Pini/SindusCon-SP: São Paulo, Brazil, 2013; ISBN 8572661077.

63. Tisaka, M. Orçamento na Construção Civil; Editora Pini: São Paulo, Brazil, 2006; ISBN 85-7266-173-5.

64. Bernardes, M.M.S. Planejamento e controle da produção para empresas de construção civil. Rio Janeiro LTC 2003.

65. Goldman, P. Introdução ao planejamento e controle de custos na construção civil brasileira; Pini: São Paulo, Brazil, 1997; ISBN 8572660720.

66. Mattos, A.D. Como Preparar OrçAmentos de Obras: DICAS Para OrçAmentistas, Estudos de Caso, Exemplos; Pini: São Paulo, Brazil, 2006; ISBN 857266176X.

67. Mattos, A.D. Planejamento e Controle de Obras; Pini: São Paulo, Brazil, 2010; ISBN 8572662235.

68. Giammusso, S.E. Orçamento e Custos na Construção Civil; Pini: São Paulo, Brazil, 1988. 
69. Dias, P.R.V. Engenharia de Custos: UMA Metodologia de OrçAmentação Para Obras Civis; Editora Copiare: São Paulo, Brazil, 2004; Volume 5.

70. Guedes, M.F. Caderno de Encargos; Pini: São Paulo, Brazil, 1987.

71. Milion, R.N.; Paliari, J.C.; Liboni, L.H.B. Improving consumption estimation of electrical materials in residential building construction. Autom. Constr. 2016, 72, 93-101. [CrossRef]

72. Brasil Decreto $n^{\circ} 7.983$, de 8 de abril de 2013. Brasília, Brazil, 2013. Available online: http:/ / www.planalto. gov.br/ccivil_03/_Ato2011-2014/2013/Decreto/D7983.htm (accessed on 21 March 2017).

73. Pereira, D.J.C.; Cardoso, D.J. EZ-BUD: ORÇAMENTAÇÃO na Nuvem; Universidade Lusófona de Humanidades e Tecnologias: Lisboa, Portugal, 2012.

74. CEHOP, Companhia Estadual de Habitação e Obras Públicas de Sergipe. Available online: http:/ / www. cehop.se.gov.br (accessed on 21 october 2017).

75. Barón Cano, J.L.; Conde Oliva, J.; Osuna Rodríguez, M.; Ramírez de Arellano Agudo, A.; Solís Burgos, J.A. Clasificación Sistemática de Precios Básicos, Auxiliares y Unitarios; Junta de Andalucía: Andalucia, Spain, 2016.

76. Junta de Andalucía. Memoria da Base de Costes de la Construcción de Andalucía-BCCA. 2017. Available online: https://www.juntadeandalucia.es/organismos/fomentoyvivienda/areas/viviendarehabilitacion/planes-instrumentos/paginas/bcca-sept-2017.html (accessed on 2 April 2018).

77. Condeixa, K.; Haddad, A.; Boer, D. Material Flow Analysis of the Residential Building Stock at the city of Rio de Janeiro. J. Clean. Prod. 2017, 149, 1249-1267. [CrossRef]

78. Shen, L.Y.; Hao, J.L.; Wing, V.; Tam, Y.; Yao, H.; Shen, L.; Tam, V.W. A checklist for assessing sustainability performance of construction projects. J. Civ. Eng. Manag. 2010, 37-41. [CrossRef]

79. de Souza, U.E.L.; Marchiori, F.F.; de Araújo, L.O.C. Variable Labor Productivity Unit Rate: Evaluation by Professionals. In Proceedings of the 10th International Symposium-CIB W65, Cincinnati, OH, USA, 9-13 September 2002.

80. BRASIL. Resolução CONAMA n 307/2002; Ministério do Meio Ambiente: Brasília, Brazil, 2002 ; p. 7. Available online: http://www2.mma.gov.br/port/conama/legiabre.cfm?codlegi=307 (accessed on 10 October 2017).

81. IBAMA, Brazilian Institute of the Environment and Renewable Natural Resources. Instrução Normativa n 13 de 18 de dezembro de 2012-Lista Brasileira de Resíduos Sólidos. Diário Of. da União 2012, 48-52.

82. Thomas, N.I.R.; Costa, D.B.; Thomas, N.I.R.; Costa, D.B. Adoption of environmental practices on construction sites. Ambient. Construído 2017, 17, 9-24. [CrossRef]

83. Saade, M.R.M.; da Silva, M.G.; Silva, V.G. Methodological discussion and piloting of LCA-based environmental indicators for product stage assessment of brazilian buildings. Gestão Tecnol. Proj. 2014, 9, 43. [CrossRef]

84. Lu, W.; Peng, Y.; Chen, X.; Skitmore, M.; Zhang, X. The S-curve for forecasting waste generation in construction projects. Waste Manag. 2016, 56, 23-34. [CrossRef]

85. Brazil NR 18-Work Conditions and Environment in the Construction Industry; Ministério do Trab. e Emprego: Brasília, Brazil, 2015. (In Portuguese)

(C) 2019 by the authors. Licensee MDPI, Basel, Switzerland. This article is an open access article distributed under the terms and conditions of the Creative Commons Attribution (CC BY) license (http://creativecommons.org/licenses/by/4.0/). 